\title{
Policy Recommendations for Korea's Vocational Education and Training (VET) Assistance to Tackle Youth Unemployment in Developing Countries
}

목 차

I. Introduction

II. Vocational Education and Training programs

1. VET in developing countries

2. Public vs. private VET

III. Korea's VET assistance to developing countries

1. Background of Korea's VET programs

2. Amount of Korea's VET assistance

3. Type of Korea's VET assistance

4. Organizational structure of Korea's VET assistance

5. Objectives and principles of Korea's VET assistance

6. Problems with Korea's VET assistance

IV. Policy options to improve Korea's VET assistance

1. Active Labor Market Programs (ALMP)

2. Career guidance programs

3. Informal sector training

$\checkmark$. Evaluation of policy options

1. Policy option \#1 - Continue current VET assistance policy

2. Policy option \#2 - Implement Active Labor Market Programs (ALMP)

3. Policy option \#3 - Provide youths with career guidance

4. Policy option \#4 - Promote informal sector training

5. Recommended policy option - Active Labor Market Programs (ALMP)

VI. Implementation strategy for recommended policy

1. Raise civil society's awareness of the problem

2. Utilize expertise of research institutes and private consulting firms

3. Ensure support from relevant government ministries

4. Start with a pilot project

5. Improve capacity of project contractors

VII. Conclusion

Reference

Appendix: Korea's VET assistance projects (2006 to 2013) 


\section{Executive summary}

There are 1.2 billion youths (population aged between 15 and 24 years old) in the world, constituting 17 percent of the world's population. With the increase in youth unemployment around the world, many countries have turned to Vocational Education and Training (VET) as a possible policy solution, both domestically and as part of their development assistance strategy. Unfortunately, the VET systems in many developing countries have critical problems such as the lack of funding, low quality of the training programs, and lack of coordination between different government ministries.

During the past few decades, the Republic of Korea (henceforth "Korea") has supported numerous VET projects in developing countries. However, there are several problems with Korea's VET assistance policies. This paper examines four policy options: 1) status-quo, 2) ALMP, 3) Career guidance, and 4) training in informal sector to improve the effectiveness of Korea’s VET assistance in addressing youth unemployment.

\section{Introduction}

According to the UN World Youth Report 2012, youths (population aged between 15 and 24 years old) make up 17 percent of the world's population, totaling 1.2 billion people. Eighty-seven percent of these youths live in developing countries. In many developing countries, the proportion of the youth population is high compared to other age groups, a phenomenon described as the "youth bulge". With good policies in place, this youth bulge could have a positive impact on the economic development of a country.

However, according to the International Labour Organization (ILO), in 2012, close to 75 million youths were unemployed worldwide, and the youth unemployment rate was 12.6 percent, three times higher than the adult unemployment rate of 4.5 percent. Biavaschi et al. (2012) also claimed that youths often face difficulties and disadvantages in the labor market compared to adults. 〈Table 1$\rangle$ and 〈Table 2$\rangle$ show the overall unemployment rate and the youth unemployment rate, respectively. According to these tables, the youth 
unemployment rate was higher than the overall unemployment rate for all levels of economies and in all years between 2005 and 2013.

Interestingly, the unemployment rate in low- and middle-income countries is lower than that of high-income countries. This reflects the differences in the economic, social, and institutional environment between developing and developed countries. While developed countries have well-designed social protection systems for the unemployed, developing countries do not. This pushes people in developing countries to take jobs that they are over-qualified for, or jobs in the informal sector which generally provide less income and other benefits to employees (King, 2012). Therefore, in spite of the seemingly low unemployment rate in developing countries, the problem of unemployment in developing countries is more serious than it looks, especially among youths.

The high unemployment rate among youths in developing countries could have negative consequences on their countries' economic development, as well as threaten the social stability (Engel, 2012). For example, the high youth unemployment rate is cited as one of the causes of the Arab Spring and the recruitment of youths into international terrorist networks (Urdal, 2006).

$\langle$ Table 2〉 Youth unemployment rate (\% of labor force) by country income classification

\begin{tabular}{l|c|c|c|c|c|c|c|c|c}
\hline & 2005 & 2006 & 2007 & 2008 & 2009 & 2010 & 2011 & 2012 & 2013 \\
\hline World & 14 & 13 & 12 & 13 & 14 & 14 & 14 & 14 & 14 \\
\hline High income countries & 15 & 15 & 14 & 14 & 18 & 18 & 18 & 18 & 18 \\
\hline $\begin{array}{l}\text { Low \& Middle income } \\
\text { countries }\end{array}$ & 13 & 13 & 12 & 13 & 13 & 13 & 13 & 13 & 13 \\
\hline Low income countries & 9 & 10 & 9 & 10 & 10 & 9 & 10 & 10 & 10 \\
\hline $\begin{array}{l}\text { Least developed countries } \\
\text { (UN classification) }\end{array}$ & 10 & 11 & 11 & 11 & 11 & 11 & 11 & 11 & 11 \\
\hline
\end{tabular}

Note: Modeled ILO estimate

Source: Created with data from World Development Indicators website

(http://databank.worldbank.org/data/views/variableSelection/selectvariables.aspx?source=world-development-indicators) 
Vocational Education and Training (VET) programs can be very effective in addressing the problem of youth unemployment. Well-designed VET programs can increase the employability of those who are not suited for academic education, giving them a second chance to enter the labor market (Meer, 2007; Hoeckel \& Schwartz, 2010). Also, VET plays an important role in producing blue-color workers demanded by the labor markets (Hoeckel, 2008). In addition, VET can contribute to social equity, because it has a higher rate of return for women and the poor, compared to other population groups (OECD, 2004).

The next section of this paper analyzes the VET system in developing countries, as well as the effectiveness of public and private VET programs. The third section explains Korea's VET assistance to developing countries, starting with the history of Korea's VET programs. It also explains the amount, type, organizational structure, objectives, and principles of Korea's VET assistance to developing countries, and points out the problems with the current policies. The fourth section presents three policy alternatives for improving Korea's VET assistance, and the fifth section evaluates these policy options on a set of criteria. The sixth section presents strategies to implement the recommended policy, which is to support Active Labor Market Programs (ALMP).

\section{Vocational Education and Training (VET) programs}

\section{VET in developing countries}

While many developed countries have established innovative VET policies to address the problem of youth unemployment (OECD, 2012; OECD, 2014), many developing countries still lack effective VET systems. The effectiveness with which developing countries bring unemployed youths into the labor market through VET programs can have a significant impact on their economic development and social stability (Urdal, 2007; Nilsson, 2010).

There are two commonly-cited problems of public VET systems in developing countries. First, many governments of developing countries do not have enough financial resources to support an effective public VET system. Thus, the budgetary allocation for public VET programs is often less than the amount that had been committed by the government. 
Second, the quality of public VET programs is low. The skills taught in public VET programs are often not aligned to labor market demands, due to the inflexible curriculum, low participation of the employers, incompetence of the instructors, and outdated training equipment (Engel, 2012).

In addition, there are problems with the overall coordination of the VET system in developing countries. VET strategies and policies are frequently addressed in various sections of the national development plans. Also, VET programs are implemented by different government bodies, such as the Ministry of Education, the Ministry of Labor, and the Ministry of Youth, without much overall coordination (Engel, 2012). The system is even more fragmented when taking into account the private sector, as there are many vocational training programs provided by the informal sector.

\section{Public vs. Private VET}

A real strength of VET is that it can help youths acquire skills, and in turn, get a job in the labor market. During the past few decades, there have been ongoing debates on whether public VET programs (conducted in public vocational training schools and institutions) or private VET programs (conducted by firms through on-the-job training) are more effective in doing this.

According to a study by Heckman (1999), public VET programs were found to be less effective and efficient compared to private VET programs. Psacharopoulos (2005) supported this claim, explaining that this was because the private sector was more responsive to the labor market demands, and also because competition in the private sector increased the effectiveness of private VET programs.

On the other hand, Bennell and Segerstrom (1998) contended that the private sector often failed to provide trainings demanded by the labor market, and that public VET programs played an important role in poverty reduction in developing countries. They (1998) also pointed out that public VET programs had played an important role in the industrialization process of Highly-Performing Asian Economics, such as Korea and Taiwan, by effectively training the youth population with skills that were needed in the labor market. 
In Germany, two papers examining the effects of public VET programs produced somewhat contradictory conclusions. Lechner (1999) claimed that despite large public expenditures on public VET programs, there were no positive effects in the first years of the program. Contrarily, Rinne et al. (2007) found that public VET programs had a positive effect on the employment rate and wages of the participants.

Due to the limited research conducted on the effectiveness of public vs. private VET programs, as well as the diversity of both public and private VET programs, it is not possible to conclude whether public or private VET programs are more effective. However, in general, private VET programs are less costly and more responsive to market demands than public VET programs.

\section{Korea's VET assistance to developing countries}

\section{Background of Korea's VET programs}

Korea's VET system played an important role in the country's rapid economic development and industrialization. Beginning in the 1960s, the Korean government established detailed economic development plans as well as corresponding VET and general education policies to produce the skills that would be needed by the new industries. The rapid development of Korea's human capital is said to have contributed significantly to the country's remarkable economic development, in spite of the country's lack of natural resources.

During the 1960s and 1970s, Korea's VET programs were centralized and supplyoriented, and the Korean government played a leading role. It was during this period that many important institutional and legal frameworks for Korea's VET system were established. In 1963, the government enacted the "Law for the Promotion of Industrial Education" and established the curriculum for vocational high schools. In 1967, the government began to implement the "Five-year Scientific Technology Education Promotion Plan (1967-1971)" (Chun \& Eo, 2012). In 1973, the "National Technical Qualification Law" was enacted to standardize the testing and certification process for technical skills, increase 
the efficiency of the VET system, and improve the quality of the technical workforce (Lee, 1989).

In 1973, the government revised the "Industrial Education Promotion Law" which made it mandatory for firms to share the costs of VET programs. According to this amendment, firms had to provide in-company training to their employees, and if the firms did not comply, they had to pay a fine which the government used to fund public VET programs (Lee, 2012). Although the goal of this policy was to increase vocational training in the private sector, many firms opted to pay the fine instead (Bennell \& Segerstrom, 1998).

During the 1960s and 1970s, the Korean government also requested international assistance to support VET programs. Aid from Germany, Japan, the United States, the World Bank, the Asian Development Bank, and the International Bank for Reconstruction and Development were used to expand the public VET system (Lee, 2009).

With the increase of vocational training schools and institutions, vocational high schools enrolled one-third of the total number of high school students in Korea at one point (Kuczera et al., 2008). The massive number of graduates from these vocational schools and institutions were easily absorbed by firms, due to the rapid economic development of the country and the high demand for skilled workers in the new industries.

In the 1980s and 1990s, many important VET institutions were also established, including the Korea Vocational Training Research Institute, the Industrial Technology Research Institute of Korea University of Technology and Education, and the Joong-Ang Vocational Training Center which trained VET instructors (Lee, 2012).

It is undeniable that Korea's VET policies played an important role in the country's rapid economic development by providing the skills that were demanded by the new industries which emerged according to the government's national development plans.

\section{Amount of Korea's VET assistance}

Korea's history of implementing successful VET policies is one reason why developing countries are actively requesting Korea's support for VET programs. As shown in 〈Table 3), Korea's VET assistance reached USD 53 million in 2013, accounting for 15.74 percent of 
Korea's Official Development Assistance for the education sector (or 4.05 percent of Korea's total bilateral Official Development Assistance). The share of Korea's Official Development Assistance for VET assistance is significantly higher than that of other donor countries (Prime Minister's Office, 2011).

〈Table 3〉 Amount of Korea's bilateral Official Development Assistance (ODA) for education and VET projects (USD million)

\begin{tabular}{c|c|c|c|c|c|c|c|c|c}
\hline Year & 2006 & 2007 & 2008 & 2009 & 2010 & 2011 & 2012 & 2013 & Ave. \\
\hline $\begin{array}{c}\text { Total bilateral } \\
\text { ODA }\end{array}$ & 376.08 & 490.54 & 539.21 & 581.1 & 900.60 & 989.52 & $1,183.17$ & $1,309.58$ & 769.23 \\
\hline $\begin{array}{c}\text { ODA for } \\
\text { Education } \\
(\%)\end{array}$ & $\begin{array}{c}135.15 \\
(35.94)\end{array}$ & $\begin{array}{c}160.17 \\
(32.65)\end{array}$ & $\begin{array}{c}112.46 \\
(20.86)\end{array}$ & $\begin{array}{c}139.02 \\
(23.92)\end{array}$ & $\begin{array}{c}324.4 \\
(36.02)\end{array}$ & $\begin{array}{c}199.17 \\
(20.13)\end{array}$ & $\begin{array}{c}127.53 \\
(10.78)\end{array}$ & $\begin{array}{c}337.05 \\
(25.74)\end{array}$ & $\begin{array}{c}191.86 \\
(24.10)\end{array}$ \\
\hline ODA for & 9.72 & 25.44 & 30.66 & 19.73 & 39.39 & $\begin{array}{c}45.32 \\
(25.75)\end{array}$ & $\begin{array}{c}47.34 \\
(37.12)\end{array}$ & $\begin{array}{c}53.07 \\
(15.74)\end{array}$ & $\begin{array}{c}33.83 \\
(17.63)\end{array}$ \\
\hline VET (\%) & $(7.19)$ & $(15.88)$ & $(27.26)$ & $(14.19)$ & $(12.14)$ & $(22.75)$ \\
\hline
\end{tabular}

Note: Net disbursement (in current prices)

Source: Author's calculation using data from OECD Aid Statistics (http://stats.oecd.org/qwids)

〈Table 4〉 indicates that the Korea International Cooperation Agency, the largest government agency executing Korea's grant aid for developing countries, spent a total of USD 143.57 million in 31 countries and 1 territory, in terms of project-type interventions, from 2006 to 2013. Annually, the Korea International Cooperation Agency spent an average of USD 17.95 million for 18 VET projects. In addition, the Economic Development Cooperation Fund, the government agency which executes Korea's loan aid for developing countries, spent a total of USD 88.21 million for VET assistance from 2006 to 2013. Annually, the Economic Development Cooperation Fund spent an average of USD 11.03 million on 5 VET projects. 
〈Table 4〉 Amount of VET assistance provided by the Korea International Cooperation Agency (KOICA) and the Economic Development Cooperation Fund (EDCF) (USD million)

\begin{tabular}{c|c|c|c|c|c|c|c|c|c}
\hline Year & 2006 & 2007 & 2008 & 2009 & 2010 & 2011 & 2012 & 2013 & Average \\
\hline $\begin{array}{c}\text { KOICA } \\
\text { (number of } \\
\text { projects) }\end{array}$ & $\begin{array}{c}6.44 \\
(15)\end{array}$ & $\begin{array}{c}17.94 \\
(19)\end{array}$ & $\begin{array}{c}11.05 \\
(17)\end{array}$ & $\begin{array}{c}8.68 \\
(7)\end{array}$ & $\begin{array}{c}15.06 \\
(17)\end{array}$ & $\begin{array}{c}24.30 \\
(21)\end{array}$ & $\begin{array}{c}22.57 \\
(22)\end{array}$ & $\begin{array}{c}37.49 \\
(29)\end{array}$ & $\begin{array}{c}17.95 \\
(18)\end{array}$ \\
\hline $\begin{array}{c}\text { EDCF } \\
\text { (number of } \\
\text { projects) }\end{array}$ & $\begin{array}{c}1.09 \\
(2)\end{array}$ & $\begin{array}{c}4.86 \\
(2)\end{array}$ & $\begin{array}{c}7.31 \\
(2)\end{array}$ & $\begin{array}{c}4.64 \\
(3)\end{array}$ & $\begin{array}{c}21.02 \\
(6)\end{array}$ & $\begin{array}{c}18.37 \\
(8)\end{array}$ & $\begin{array}{c}19.88 \\
(9)\end{array}$ & $\begin{array}{c}11.04 \\
(5)\end{array}$ & $\begin{array}{c}11.03 \\
(5)\end{array}$ \\
\hline
\end{tabular}

Note 1: Net disbursement (in current prices)

Note 2: Only project-type interventions are included. Project-type interventions account for more than 90 percent of the Korea International Cooperation Agency's VET interventions (PMO, 2011). Other types of interventions include Public-Private Partnerships and support to NGOs.

Source: Author's calculations using data from OECD Aid Statistics (http://stats.oecd.org/qwids)

\section{Type of Korea's VET assistance}

Korea's VET assistance in developing countries focuses mostly on strengthening the public VET system by building vocational training schools and institutions. To support these schools and institutions, Korea also gives support for vocational training programs, provides equipment and training materials, dispatches technical advisors, and invites trainees to attend trainings in Korea (Chun \& Eo, 2012).

〈Table 5〉 shows that between 2006 and 2013, nearly 90 percent of Korea's VET assistance projects were based in vocational training schools and institutions. (The full list

〈Table 5〉 Korea's VET assistance projects based in schools and institutions

\begin{tabular}{c|c|c|c|c|c|c|c|c|c}
\hline Year & 2006 & 2007 & 2008 & 2009 & 2010 & 2011 & 2012 & 2013 & Total \\
\hline $\begin{array}{c}\text { Number of } \\
\text { VET projects }\end{array}$ & 17 & 21 & 19 & 10 & 23 & 29 & 31 & 34 & 184 \\
\hline $\begin{array}{c}\text { Number of } \\
\text { school and } \\
\text { institution- } \\
\text { based VET } \\
\text { projects } \\
\text { (\% of above) }\end{array}$ & $\begin{array}{c}15 \\
(88.24)\end{array}$ & $\begin{array}{c}20 \\
(95.24)\end{array}$ & $\begin{array}{c}17 \\
(89.47)\end{array}$ & $\begin{array}{c}10 \\
(100)\end{array}$ & $\begin{array}{c}20 \\
(86.96)\end{array}$ & $\begin{array}{c}26 \\
(89.66)\end{array}$ & $\begin{array}{c}28 \\
(90.23)\end{array}$ & $\begin{array}{c}29 \\
(85.29)\end{array}$ & $\begin{array}{c}165 \\
(89.67)\end{array}$ \\
\hline
\end{tabular}

Note: Projects with unclear information on activities and objectives were not counted (i.e. Colombia-Triangular Cooperation Project, Ethiopia-Project for Vocational Capacity Building, Vietnam National Skill Testing Systems)

Source: Author's calculation using data from OECD Aid Statistics (http://stats.oecd.org/qwids) 
of Korea's VET assistance projects from 2006 to 2013 is included in the Appendix.) Korea' s focus on this type of VET assistance reflects its own history of implementing successful VET policies in the past, as explained above.

\section{Organizational structure of Korea's VET assistance}

All of Korea's Official Development Assistance policies are coordinated by the Committee of International Development Cooperation under the Prime Minister's Office. In 2011, this committee established Korea's first mid-term Official Development Assistance policy for 2011 to 2015, which serves as the government's overarching strategy for administering its Official Development Assistance to developing countries (OECD, 2013).

At the ministerial level, both the Ministry of Strategy and Finance and the Ministry of Foreign Affairs are key institutions in Korea's VET assistance policies. These ministries supervise the Economic Development Cooperation Fund and the Korea International Cooperation Agency, respectively, which are the implementing agencies for Korea's VET assistance projects. These projects are usually sub-contracted to governmental and semigovernmental organizations, such as Human resource Development Korea (HDR Korea), the Korean Chamber of Commerce (Korcham), Korea University of Technology and Education, and Korea Polytechnics. The stakeholders involved in Korea's VET assistance are depicted in $\langle$ Exhibit 1〉.

\section{〈Exhibit 1〉 Stakeholders involved in Korea's VET assistance}

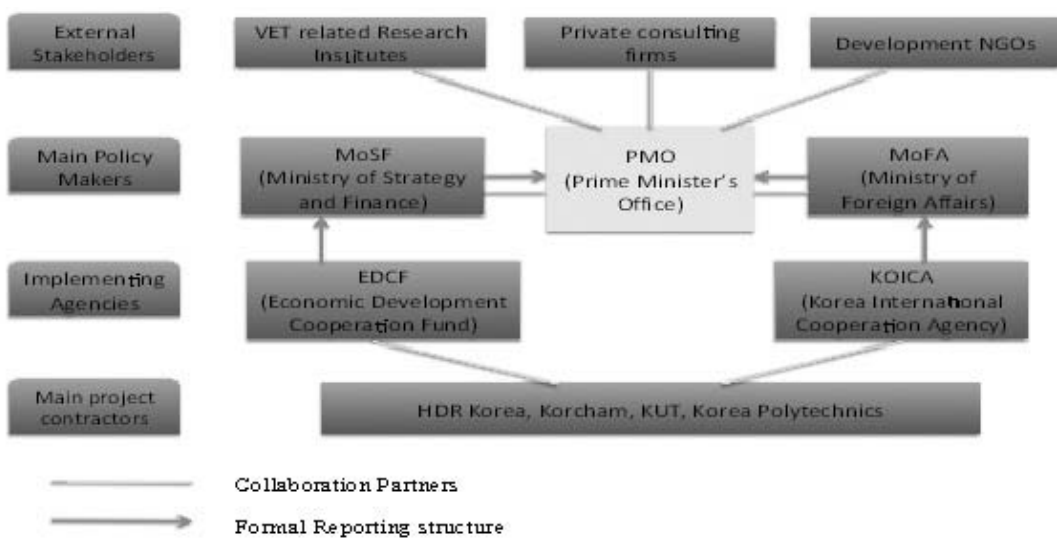

Source: made by author 


\section{Objectives and principles of Korea's VET assistance}

According to the mid-term Official Development Assistance policy for 2011 to 2015 established by the Prime Minister's Office, the education sector is one of the priority sectors for Korea's development assistance. The goal of Korea's educational assistance is to enhance the productivity and employability of workers in developing countries (Prime Minister's Office, 2010).

In 2011, the Prime Minister's Office reconfirmed VET to be one of its priority sectors in its educational assistance to developing countries, given the competitiveness of Korea' s VET sector and Korea's own development experience based on government-led VET interventions (Prime Minister's Office, 2011). The overarching goal of Korea's VET assistance is to increase the human capital of developing countries by establishing training infrastructure, providing quality vocational education and training, and enhancing the capacity of the VET sector (Chun \& Eo, 2012).

The Prime Minister's Office also presented two principles for Korea's VET assistance. The first principle is that the recipient countries of Korea's VET assistance should be selected after a careful analysis of the countries' labor market and industries, taking into account their specific VET demands. The second principle is that Korea's VET assistance should follow a program-based approach, covering various areas such as institutional reforms, training infrastructure, and capacity building. This is in contrast to the standalone project approach of the past.

\section{Problems with Korea's VET assistance}

As explained above, Korea's VET assistance mostly focuses on strengthening the recipient country's public VET system by building vocational training schools and institutions. Such an emphasis on strengthening the public VET system reflects Korea' s own development experience. However, this strategy may not be effective in developing countries that have a different social and economic context from Korea's past.

In addition, there are several problems with the stated goal of Korea's VET assistance, which is to "increase the human capital of recipient countries." First, developing human 
capital through VET programs will not necessarily address the problem of unemployment, which is the real issue that should be tackled in developing countries. Thus, the link between the VET programs and employment should be expressed more clearly in the goals of the VET programs. Second, in terms of increasing human capital, VET programs are less effective than general education. Psacharopoulos (1994) examined the rates of return to education worldwide, and found that the rate of return to vocational education was 10.6 percent, while the rate of return for general education was 15.5 percent. Also, in terms of graduates' income, VET is less cost-effective compared to general education, since vocational education has higher costs due to more expensive equipment, higher maintenance costs, and smaller classes (Psacharopoulos, 2005; IIEP, 2007). Therefore, since VET is neither the most effective nor the most cost-effective way to increase human capital, stating this as the goal of Korea's VET assistance does not make sense. Instead, as stated above, the primary goal of VET programs should be to increase the employment rate among the graduates of the VET programs.

Another problem is that the implementing agencies do not have a clear strategy for their VET assistance. According to the Korea International Cooperation Agency (2013), the goal of its VET assistance is to develop a skilled workforce in recipient countries. However, it does not have a systematic approach for its VET assistance or specific areas for support. In the case of the Economic Development Cooperation Fund, it only has policy-level guidelines for its VET assistance which were largely set by the Committee of International Development Cooperation (Economic Development Cooperation Fund, 2013), and its strategies and specific areas of support are very vague.

Without addressing the issues mentioned above, Korea's VET assistance will not be as effective as it could be.

\section{Policy options to improve Korea's VET assistance}

This section will present possible policy options to improve Korea's VET assistance to developing countries. These policies have been proven to be effective in addressing youth unemployment in developing countries. 


\section{Active Labor Market Programs (ALMP)}

Active Labor Market Programs (ALMP) include a broad range of interventions such as job search assistance, in-classroom and on-the-job trainings based on market demand, subsidized employment opportunities, and support for entrepreneurship. Although the effects of ALMPs vary across the programs, well-designed ALMPs can be effective in addressing youth unemployment by equipping youths with marketable skills (Biasvaschi et al., 2012).

Since ALMPs include a wide range of policy options, countries are able to choose the alternative that best fits their needs and situation. For example, job search assistance programs will be effective in countries that are aiming for high impact in the short-term, while in-classroom and on-the-job training will be effective in countries that are aiming for medium and long-term impact (Card et al., 2010).

ALMPs have been proven to be successful in addressing youth unemployment in many developing countries. For example, in Nepal, the Employment Fund ${ }^{1)}$ was a very successful ALMP that focused on on-the-job training, apprenticeships, and market-oriented shortterm training for youths, women, and other marginalized people. From 2008 to 2013, more than 70,000 young people were trained through this program, and more than seventy percent of them remained employed three years after the trainings. In 2013, this program won the second prize in the International Labour Organization's call for good practices on youth employment.

In the Middle East and North Africa, an NGO called Education for Employment ${ }^{2)}$ has also been implementing successful ALMPs. This NGO provides employability trainings, shortterm job trainings, and entrepreneurship trainings to help unemployed youths find jobs.

\section{Career guidance programs}

In developing countries, many youths lack information about the careers that are available to them in the labor market. As a consequence, many do not give careful thought

1) Website: http://employmentfund.org.np

2) Website: http://www.efe.org/ 
to their career and education choices, which leads to a higher likelihood for them to be unemployed, compared to those who receive proper career guidance.

According to the Organisation for Economic Cooperation and Development (OECD), career guidance is defined as services and activities intended to assist individuals of any age, at any point in their lives, to make choices regarding their education, training, and occupation, as well as to manage their career (Hansen, 2006). Career guidance programs can help youths identify and pursue available jobs, find relevant training resources, and make informed decisions about their educational path (OECD, 2014). This can prevent some youths from blindly pursuing higher education with the expectation of getting a higherpaying job, only to be unemployed at the end of their studies. This way, career guidance programs can also help reduce the social and cultural misperceptions of VET, especially in countries where VET is regarded as an inferior educational option for students.

\section{Informal sector training}

In developing countries, informal training (such as apprenticeships) is prevalent, because the size of the informal sector is large. Compared to formal VET, which is often inflexible and lacks the involvement of employers, informal training is very responsive to the demands of the labor market, since it is provided directly by the employers. Also, informal training focuses on work-based learning, consistent with the current trends in VET (OECD, 2014). Some even claim that participants of informal training have higher employability than those who participated in formal VET programs (Biavachi et al., 2012). For these reasons, promoting informal training can be an effective policy for addressing youth unemployment in developing countries.

However, informal training has some critical problems regarding certification and quality assurance. In addition, informal training is weak in increasing general skills which increases workers' flexibility and adaptability in the labor market. Also, in developing countries, informal training increases the possibility of exploiting children and marginalized people, due to the lack of regulations and monitoring. Therefore, proper regulations and guidelines for informal training are necessary to protect the rights of the trainees while ensuring the quality of the trainings. 


\section{Evaluation of policy options}

As mentioned before, VET programs can be very effective in addressing the problem of youth unemployment in developing countries. However, if the VET programs are not carefully designed, youths who participate in the program may not be able to find jobs later, which can increase their frustration, possibly leading to social instability (Urdal, 2007). Thus, it is important for donors to make sure their VET assistance directly addresses the issue of youth unemployment.

In order to make Korea's VET assistance more effective in addressing youth unemployment, the three policy options presented above, as well as the option of maintaining the current policy, will be evaluated on a set of five criteria. This analysis may prove to be useful at the policy level, as well as the implementation level of Korea's VET assistance programs.

The criteria for assessing the policy options are:

- Effectiveness in addressing youth unemployment

- Political feasibility among policy makers in Korea

- Technical practicality

- Local participation

- Financial sustainability in recipient countries

$\langle$ Exhibit 2〉 summarizes the results of the evaluation of each policy options using the five criteria.

〈Exhibit 2〉 Matrix of policy options and key criteria

\begin{tabular}{c|c|c|c|c|c}
\hline Criteria & Effectiveness & $\begin{array}{c}\text { Political } \\
\text { feasibility }\end{array}$ & $\begin{array}{c}\text { Technical } \\
\text { practicality }\end{array}$ & $\begin{array}{c}\text { Local } \\
\text { participation }\end{array}$ & $\begin{array}{c}\text { Financial } \\
\text { sustainability }\end{array}$ \\
\hline $\begin{array}{c}\text { Option \#1: } \\
\text { Current policy }\end{array}$ & $*$ & $*$ & $*$ & $*$ \\
\hline $\begin{array}{c}\text { Option \#2: } \\
\text { ALMP }\end{array}$ & $*$ & $*$ & $*$ & $*$ & $*$ \\
\hline $\begin{array}{c}\text { Option \#3: } \\
\text { Career guidance }\end{array}$ & $*$ & $*$ & & $*$ & $*$ \\
\hline $\begin{array}{c}\text { Option \#4: } \\
\text { Informal sector } \\
\text { training }\end{array}$ & $*$ & & & $*$ \\
\hline
\end{tabular}




\section{Policy option \#1 - Continue current VET assistance policies (focusing on public VET programs in vocational training schools and institutions)}

Continuing the current VET assistance policy is the easiest option in many ways. It meets the criteria of political feasibility, because it fits in well with the Korean government' s overarching aid policy of promoting Korean-style development assistance based on Korea's own development experience (OECD, 2013). Also, it meets the criteria of technical practicality, because for more than two decades, the Korea International Cooperation Agency and the Economic Development Cooperation Fund have been implementing this type of VET assistance in developing countries.

However, as mentioned previously, this policy option does not meet the criteria of effectiveness, because public VET programs are often less effective than private or marketoriented training programs. The curriculum is inflexible due to administrative obstacles, and there is limited participation from the employers. Furthermore, this policy option does not meet the criteria of financial sustainability, because it is expensive to maintain highquality training programs in public VET schools and institutions. Considering that Korea' s VET assistance often stops once the training school or institution is constructed, and that the governments of developing countries often lack fiscal resources to support public programs, this policy option is not financially sustainable in the long-run.

\section{Policy option \#2 - Implement Active Labor Market Programs (ALMP)}

As mentioned before, ALMPs include a broad range of interventions, including job search assistance, in-classroom and on-the-job trainings based on the market demand, subsidized employment opportunities, and support for entrepreneurship. Thus, it can be tailored to the needs of each country.

ALMPs are very effective in addressing youth unemployment. In particular, on-thejob trainings provide unemployed youths with valuable experience which can help them prepare for the labor market. Also, job search assistance reduces the unemployment spell among youths by addressing the information asymmetry in the job market. 
Although ALMPs are not categorized as Korean-style development programs, most ALMP interventions are commonly implemented in Korea, and the main contractors that are carrying out Korea's VET assistance in developing countries also have experience implementing these programs in Korea. Thus, introducing ALMPs into Korea's VET assistance will be politically as well as technically feasible. (However, subsidizing the public sector employment programs may meet some political opposition, due to the reluctance of the Korean government in providing development assistance in the form of subsidies.)

Another advantage of ALMPs is that it can increase local participation, because ALMPs directly involve employers and the local community in the implementation of on-the-job trainings and job search assistance. In addition, ALMPs are financially sustainable, because it does not require the maintenance of expensive training institutions and equipment. Also, existing public institutions (such as community centers), NGOs, and private training providers can efficiently provide youths with various trainings and job search assistance.

\section{Policy option \#3 - Provide youths with career guidance}

Currently, VET is often provided as remedial support for youths who lack marketrelevant skills. By providing youths and their parents with career guidance, there will be less demand for remedial support, because they will be able to make more informed choices beforehand about their career and educational path.

As mentioned above, by giving information to youths about the jobs available in the labor market, youths can make informed decisions about their education and career, and it can also address the misperceptions that VET is an inferior educational option. Thus, it is an effective policy option for addressing youth unemployment in the long run. (However, it may not be effective in the short run, because it will take time to reap the benefits.) In addition, this option is financially sustainable, because it does not require as much resources as maintaining public VET schools and institutions. Also, this policy can increase the involvement of the local community, because career guidance programs will be based on information provided by local firms.

However, this policy option may not be politically feasible, considering the Korean policy makers' preference for supporting Korean-style development assistance. Another drawback 
is that career guidance can be biased towards traditional gender roles and limited options for marginalized groups.

\section{Policy option \#4 - Promote informal sector training}

Considering the large informal sector in developing countries, promoting training in the informal sector could be an effective policy option to address youth unemployment. The bigger the informal sector in a country, the bigger the impact of informal sector training will be.

As mentioned above, informal sector training can be effective in providing marketable skills and valuable work experience for youths, and it is also very responsive to the skills demand of the labor market, because it is provided directly by the employers. By definition, it also involves local participation. In addition, it is financially sustainable, since it does not require much financial support other than to standardize the informal training system.

However, the main contractors that are implementing Korea's VET assistance have little experience in supporting informal sector training, so it does not meet the criteria of technical practicality. Also, it will be politically difficult to push for this option, since policy makers in Korea prefer development assistance programs based on Korea's own development experience.

\section{Recommended policy option-Active Labor Market Programs (ALMP)}

Based on the evaluation above, promoting ALMPs is the best policy option to improve Korea's VET assistance in developing countries. This is the only policy option that meets all five criteria of effectiveness, political feasibility, technical practicality, local participation, and financial sustainability. First, it is effective in addressing youth unemployment, especially when it is designed to be flexible and market-oriented. Second, it is politically feasible, because the Korean government is familiar with ALMPs which are also being implemented in Korea. Third, it meets the criteria of technical practicality, because the implementing agencies of Korea's VET assistance have experience implementing ALMPs domestically. Fourth, it ensures local participation, because ALMPs directly involve 
employers and the local community in on-the-job trainings and job search assistance. Lastly, it is financially sustainable, because it does not require the maintenance of expensive training institutions and equipment.

\section{Implementation strategy for recommended policy}

For the Korean government to adopt the policy recommendation above, a holistic strategy needs to be taken by the various stakeholders, such as the civil society, research institutes and private consulting firms, relevant government ministries, implementing agencies, and project contractors. This section describes how to involve each stakeholder, ensure their support, and ultimately create a favorable environment for the Korean government to adopt a new VET assistance policy. Although it may be challenging to carry out all the steps mentioned below, it is important to involve as many stakeholders as possible in adopting this new policy.

\section{Raise civil society's awareness of the problem}

In recent years, as Korea's budget for foreign aid increased, so has the general public' s interest in monitoring how the foreign aid is being used. In particular, NGOs involved in development assistance are making efforts to raise the public's awareness of Korea's official development assistance, while also demanding transparency and accountability from the Korean government. For example, ODA Watch ${ }^{3)}$ is one of the most active NGOs in Korea to monitor Korea's official development assistance. The Korean government pays close attention to the demands and criticisms of the civil society, since its official development assistance is financed through tax payers' money.

Therefore, one of the first steps in changing Korea's VET assistance policy would be to gain the support of the civil society. This can be done by making the civil society understand that there are problems with Korea's current VET assistance, and that there are more effective policy options, such as supporting ALMPs.

3) Website: https://odawatch.wordpress.com 
The civil society will be enthusiastic in supporting this, since they are concerned with increasing the effectiveness of Korea's development assistance. However, one problem is that the civil society often lacks sector-specific expertise, so they may not have the capacity to engage in a policy discourse about the specific problems with Korea's current VET assistance policy and the way forward. Nevertheless, this shortcoming can be overcome through cooperation with research institutes and private consulting firms, as explained below.

\section{Utilize expertise of research institutes and private consulting firms}

Research institutes and private consulting firms can be helpful in producing rigorous research and evidence on the problems with Korea's current VET assistance policies as well as strategies for improvement.

There are many public research institutes in Korea with expertise in VET and development assistance, including the Korea Research Institute for Vocational Education and Training (KRIVET), ${ }^{4)}$ the Korea Labor Institute (KLI), ${ }^{5)}$ and the Korea Educational Development Institute (KEDI). ${ }^{6}$ The main responsibility of these public research institutes is to analyze Korea's public policies and suggest policy alternatives. Although most of these public research institutes focus on domestic issues, some of these institutes have experience participating in the VET assistance projects of the Korea International Cooperation Agency and the Economic Development Cooperation Fund, placing them in a good position to provide expertise in this area.

There are also a number of private consulting firms in Korea that focus on Korea' s foreign aid policies, including the Re-shaping Development Institute (ReDI), ${ }^{7)}$ the Korea Institute for Development Strategy (KDS), ${ }^{8)}$ and the Korea Association for
4) Website: http://eng.krivet.re.kr/eu/index.js
5) Website: http://www.kli.re.kr/kli_ehome/main/main.jsp
6) Website: http://eng.kedi.re.kr/khome/eng/webhome/Home.do
7) Website: http://redi.re.kr/?lang=en
8) Website: http://eng.kds.re.kr/Main/index.html 
International Development Cooperation (KAIDEC). ${ }^{9)}$ In 2011, the Development Alliance Korea (DAK) was established as a cooperative network between the government and the private sector, providing a channel for the private sector to participate in the field of development assistance. These private consulting firms can produce rigorous research and evidence on the problems with Korea's current VET assistance policy as well as strategies to improve it.

\section{Ensure support from relevant government ministries}

Besides the Prime Minister's Office, two ministries exercise significant influence on Korea's development assistance policies. They are the Ministry of Strategy and Finance (which administers loans to developing countries through the Economic Development Cooperation Fund) and the Ministry of Foreign Affairs (which administers grant aid to developing countries through the Korea International Cooperation Agency). Under the leadership of the Prime Minister's Office, these two ministries discuss major policy issues regarding Korea's foreign aid, such as the Country Partnership Strategy for specific countries, the annual aid budget allocation plan, and Korea's mid-term foreign aid policy.

However, these two ministries have a competitive relationship when it comes to the budget, because each ministry is aiming to increase their share of Korea's budget for development assistance. Also, a lack of coordination and communication between these two ministries can pose a barrier to agreeing on an alternative VET assistance policy. Even if the Prime Minister's Office were to unilaterally decide to shift Korea's VET assistance policy, it will not be effective on the ground without the buy-in from these two implementing ministries.

Therefore, in order to effectively change Korea's VET assistance policy, it is necessary to get both the Ministry of Strategy and Finance and the Ministry of Foreign Affairs on board. They should hold regular meetings to discuss the problems regarding Korea's current VET assistance policy, as well as ways to improve it.

9) Website: http://www.kaidec.org/english/ 


\section{Start with a pilot project}

After the Korean government decides to change its VET assistance at the policy-level, the new policies should be tested through small-scale pilot projects. Even though many of the implementing agencies have experience conducting ALMPs in Korea, the context of each country is different, so the programs will need to be customized to the needs and challenges of each country. Thus, the pilot projects will give the implementing agencies a chance to improve the project design and fix any unforeseen problems before the projects are scaled up.

When designing the pilot projects, the Korea International Cooperation Agency and the Economic Development Cooperation Fund should review the ALMPs that have been successful in developing countries, such as the Employment Fund in Nepal and the NGO Education for Employment's work the Middle East and North Africa. By reviewing these projects, they will be able gain valuable insights into how to effectively implement ALMPs in developing countries, while learning from the mistakes that had already been made. In addition, they should also review the VET assistance projects that they implemented in the past, which will help them understand the challenges and opportunities in each country, as well as their own strengths and weaknesses.

\section{Improve capacity of project contractors}

Lastly, in order to make the new policy successful, it is very important to improve the project contractors' capacity for implementing ALMPs in developing countries.

Due to Korea's history of focusing on public sector VET programs, governmental and semi-governmental agencies (such as Human Resource Development Korea, the Korean Chamber of Commerce, Korea Polytechnics, and Korea University of Technology and Education) have been the major project contractors to implement Korea's VET assistance projects in developing countries. As government agencies, they have an equal footing with the Korea International Cooperation Agency and the Economic Development Cooperation Fund, so they can also have an influence on the policy-making process. For these reasons, it is very important to get these project contractors on board in order to change the direction of Korea's VET assistance, as well as to develop their capacity for this new type 
of assistance.

Although these project contractors have carried out ALMP interventions in Korea to address youth unemployment since the 1990s, they do not have experience implementing similar types of programs in developing countries where the socio-economic environment is very different from Korea's. Therefore, it is very important to improve their capacity in designing and implementing ALMPs that are suitable for developing countries. Inviting them to participate in pilot projects can be a good opportunity for them to develop these capacities and to understand the importance of changing the direction of Korea's VET assistance.

\section{Conclusion}

With the increase in youth unemployment around the world, many countries have turned to VET as a possible policy solution, both domestically and as part of their development assistance strategy. Korea is at the forefront of providing VET assistance to developing countries, based on its own experience of establishing an effective public VET system which contributed to the country's rapid economic development. Although continuing the current VET assistance policy would be the easiest option for the Korean government in many ways, it is not the most effective way to tackle the problem of youth unemployment in developing countries.

This paper found that promoting ALMPs would be the best policy option for improving Korea's VET assistance to developing countries. First, ALMPs will be effective in addressing youth unemployment, especially when it is designed to be flexible and market-oriented. Second, it is politically feasible, because the Korean government is familiar with ALMPS which are also being implemented in Korea. Third, it meets the criteria of technical practicality, because the implementing agencies of Korea's VET assistance have experience implementing ALMPs domestically. Fourth, it ensures local participation, because ALMPs directly involve employers and the local community in on-the-job trainings and job search assistance. Lastly, it is financially sustainable, because it does not require the maintenance of expensive training institutions and equipment. 
For the Korean government to adopt this new VET assistance policy, a holistic strategy needs to be taken by the various stakeholders, including the civil society, research institutes and private consulting firms, relevant government ministries, implementing agencies, and project contractors. By following the strategies outlined in this paper, Korea will be able to improve its VET assistance policies so it can better tackle the problem of youth unemployment in developing countries, contributing to their economic development and social stability. 


\section{〈References〉}

Ajufo, B. I. (2013). "Challenges of youth unemployment in Nigeria: effective career guidance as a panacea." African Research Review. 7(1). 307-321

Alam, G. M. (2008). "The role of technical and vocational education in the national development of Bangladesh." Asia-Pacific Journal of Cooperative Education. 9(1). 25-44

Axmann, M. (2004). "Facilitating Labour Market Entry for Youth through Enterprise-based schemes in Vocational Education and Training and Skills Development”. SEED Working Paper(48). Geneva: International Labour Organization (ILO)

Bennell, P., \& Segerstrom, J. (1998). "Vocational education and training in developing countries: Has the World Bank got it right?" International Journal of Educational Development. 18(4). 271-287

Biavaschi, C., Eichhorst, W., Giulietti, C., Kendzia, M. J., Muravyev, A., Pieters, J., Zimmermann, K. F. (2012). "Youth unemployment and vocational training"

Buddelmeyer, H., \& Herault, N. (2010). "The Role of VET in Preventing the Scarring Effect of Youth Joblessness". A National Vocational Education and Training Research and Evaluation Program Report: ERIC

Card, D., Kluve, J., \& Weber, A. (2010). “Active Labour Market Policy Evaluations: A Meta Analysis”. The Economic Journal, 120(548). F452-F477

Chun, H. M., Eo, K. C. (2012). “Aid for Skills Development: South Korea Case Study”. Background paper prepared for the Education for All Monitoring Report 2012: UNESCO

Dundar, H., Millot, B., Savchenko, Y., Aturupane, H., \& Piyasiri, T. A. (2014). Building the skills for economic growth and competitiveness in Sri Lanka: World Bank Publications

EDCF (2013). EDCF Annual Report 2012. Economic Development Cooperation Fund (EDCF)

Engel, J. (2012). "Review of policies to strengthen skills-employment linkages for marginalized young people”. Background paper prepared for the Education for 
All Monitoring Report 2012: UNESCO

Hansen, E. (2006). Career guidance: A Resource Handbook for Low-and MiddleIncome Countries. Geneva: ILO

Heckman, J. J. (1999). “Doing It Right: Job Training and Education”. Public Interest. 135. 86-107

Hilson, G., \& Osei, L. (2014). “Tackling youth unemployment in sub-Saharan Africa: Is there a role for artisanal and small-scale mining?" Futures. 62. 83-94

Hoeckel, K. (2008). Costs and benefits in vocational education and training. Paris: Organisation for Economic Cooperation and Development (OECD)

Hoeckel, K., \& Schwartz, R. (2010). Learning for Jobs: OECD Reviews of Vocational Education and Training-Austria. Paris: Organisation for Economic Co-operation and Development (OECD)

Horowitz, A. W., \& Schenzler, C. (1999). "Returns to general, technical and vocational education in developing countries: recent evidence from Suriname”. Education Economics. 7(1). 5-20

IIEP (2007). "Vocational education and training for youth". International Institute for Educational Planning Newsletter. XXV. N 4

ILO (2012). Global Employment Trends for Youth 2012. Geneva: International Labour Organization (ILO)

ILO (2013). Global Employment Trends for Youth 2013: A generation at risk. Geneva: International Labour Organization (ILO)

KOICA (2013). 2012 KOICA Annual report. Korea International Cooperation Agency (KOICA)

Kuczera, M., Kis, V., \& Wurzburg, G. (2008). Learning for Jobs OECD Reviews of Vocational Education and Training Korea. Paris: Organisation for Economic Cooperation and Development (OECD)

Lechner, M. (1999). “An evaluation of public-sector-sponsored continuous vocational training programs in East Germany". University of St. Gallen Working Paper (9901)

Lee, S. J. (1989). National Technical Qualification System in Korea. Seoul: Korea Vocational Training and Management Agency (KVTMA) 
Lee, Y. H. (2009). Vocational education and training in the process of industrialization. Seoul: Korean Educational Development Institute (KEDI)

Malamud, O., \& Pop-Eleches, C. (2010). "General education versus vocational training: Evidence from an economy in transition". The review of economics and statistics. 92(1). 43-60

McGrath, S. (2012). "Vocational education and training for development: A policy in need of a theory?” International Journal of Educational Development. 32(5). $623-631$

Meer, J. (2007). "Evidence on the returns to secondary vocational education". Economics of education review. 26(5). 559-573

Middleton, J., Ziderman, A., Van Adams, A. (1993). Skills for productivity : vocational education and training in developing countries. New York, NY: Oxford University Press

Nilsson, A. (2010). "Vocational education and training-an engine for economic growth and a vehicle for social inclusion?" International Journal of Training and Development. 14(4). 251-272

Nordman, C. J., \& Pasquier-Doumer, L. (2014). "Vocational education, on-the-job training, and labour market integration of young workers in urban West Africa”. PROSPECTS. 44(3). 445-462

OECD (2004). "Improving Skills for More and Better Jobs: Does Training Make a Difference?" In OECD, Employment Outlook 2004 (pp. 183-224). Paris: OECD OECD (2010). Learning for jobs: Synthesis Report of the OECD Reviews of Vocational Education and Training. Paris: OECD

OECD (2013). OECD Development Assistance Peer Reviews: Korea 2012. Paris: OECD

OECD (2014). Skills Beyond School: Synthesis Report of OECD Reviews of Vocational Education and Training, Paris: OECD

Pillay, P. (2010). Linking higher education and economic development: Implications for Africa from three successful systems: African Books Collective PMO (2010). Mid-term ODA Policy (2011-2015). Seoul: Prime Minister's Office $(\mathrm{PMO})$ 
PMO (2011). National Strategy on Aid for Vocational Education and Training. Seoul: Prime Minister's Office (PMO)

Psacharopoulos, G (1994). "Returns to investment in education: A global update". World development. 22(9). 1325-1343

Psacharopoulos, G (2005). "Linking Vocational Education and Training Research, Policy and Practice: A Personal View”. European Journal: Vocational Training, 36. $69-73$

Rinne, U., Schneider, M., \& Uhlendorff, A (2007). "Too bad to benefit? Effect heterogeneity of public training programs”. IZA Discussion Papers, No. 3240

Tripney, J. S., \& Hombrados, J. G (2013). “Technical and vocational education and training (TVET) for young people in low-and middle-income countries: a systematic review and meta-analysis”. Empirical Research in Vocational Education and Training. 5(1). 1-14

Urdal, H (2006). "A clash of generations? Youth bulges and political violence". International Studies Quarterly. 50(3). 607-629

Urdal, H (2007). “The Demographics of Political Violence: Youth Bulges, Insecurity, and Conflict”. In Brainard, L., \& Chollet, D. H. (Eds.), Too poor for peace? Global poverty, Conflict, and Security in the 21st Century (pp. 90-100). Brookings Institution Press

World Bank (2011). Learning for All: Investing in People's Knowledge and Skills to Promote Development: World Bank Group Education Strategy 2020. World Bank 


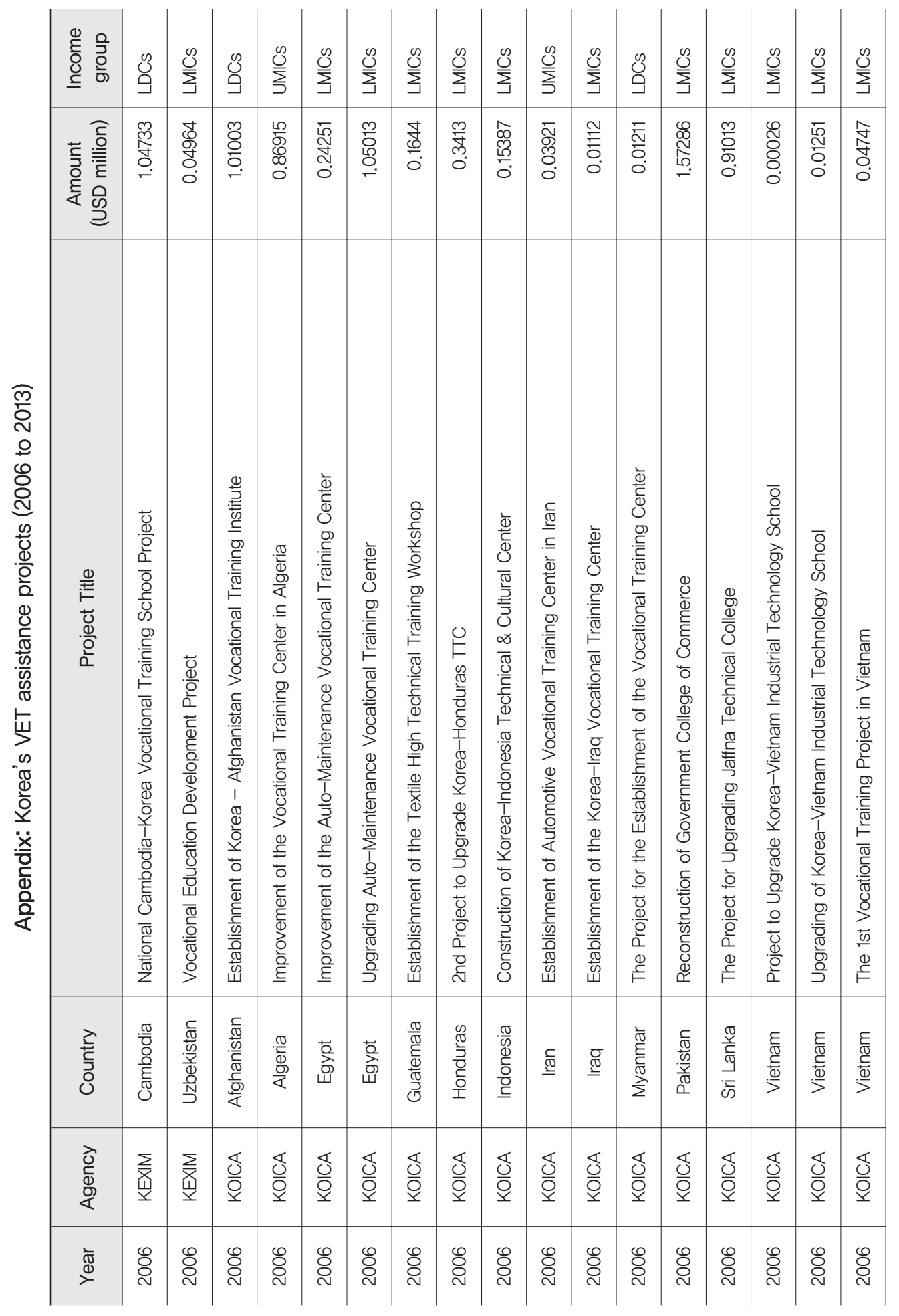

\section{제I장}

제II장

섹

터

제III장 


\begin{tabular}{|c|c|c|c|c|c|c|c|c|c|c|c|c|c|c|c|c|c|c|}
\hline $\begin{array}{l}0 \\
\text { O }\end{array}$ & $\sum_{3}^{\infty}$ & 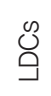 & $\stackrel{\infty}{\sum}$ & $\stackrel{\mathcal{O}}{\sum}$ & $\stackrel{\mathcal{U}}{\sum}$ & $\stackrel{\mathcal{S}}{\sum}$ & 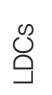 & $\stackrel{\infty}{\sum}$ & $\sum_{\Sigma}^{\mathcal{S}}$ & $\stackrel{\mathcal{O}}{\sum}$ & $\stackrel{\mathcal{S}}{\sum}$ & $\stackrel{\mathcal{O}}{\sum}$ & $\sum_{\zeta}^{\infty}$ & $\stackrel{\mathcal{S}}{\sum}$ & $\begin{array}{l}\text { y } \\
\text { S }\end{array}$ & $\sum_{\Sigma}^{\infty}$ & $\sum_{\Sigma}^{\mathcal{O}}$ & $\frac{\mathcal{O}}{\sum}$ \\
\hline $\begin{array}{l}\bar{E} \\
\overline{0} \\
\infty \\
0 \\
0\end{array}$ & $\begin{array}{l}\stackrel{8}{0} \\
\stackrel{\leftrightarrow}{\mathbb{N}} \\
\stackrel{0}{0}\end{array}$ & $\begin{array}{l}\hat{0} \\
\text { 을. } \\
\stackrel{0}{c}\end{array}$ & 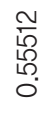 & $\begin{array}{l}\stackrel{\mathscr{ల}}{\widetilde{O}} \\
\stackrel{0}{E}\end{array}$ & 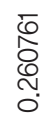 & $\begin{array}{l}\hat{0} \\
\stackrel{8}{O} \\
0 \\
0 \\
0\end{array}$ & $\begin{array}{l}\mathcal{E} \\
\stackrel{R}{R} \\
\forall \\
\forall\end{array}$ & $\begin{array}{l}\text { 守 } \\
\text { O. } \\
\text { ○ }\end{array}$ & $\begin{array}{l}\overline{\mathbb{N}} \\
\infty \\
\infty \\
\stackrel{0}{0} \\
0\end{array}$ & 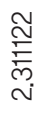 & $\begin{array}{l}\infty \\
\infty \\
0 \\
0 \\
\stackrel{0}{0} \\
\forall\end{array}$ & 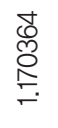 & $\begin{array}{l}\frac{0}{0} \\
\frac{0}{10} \\
\frac{10}{+}\end{array}$ & 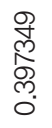 & 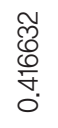 & $\begin{array}{l}\tilde{\delta} \\
\text { గ్ } \\
0 \\
0 \\
0 \\
0\end{array}$ & 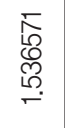 & $\begin{array}{l}0 \\
\mathscr{O} \\
\\
\end{array}$ \\
\hline
\end{tabular}

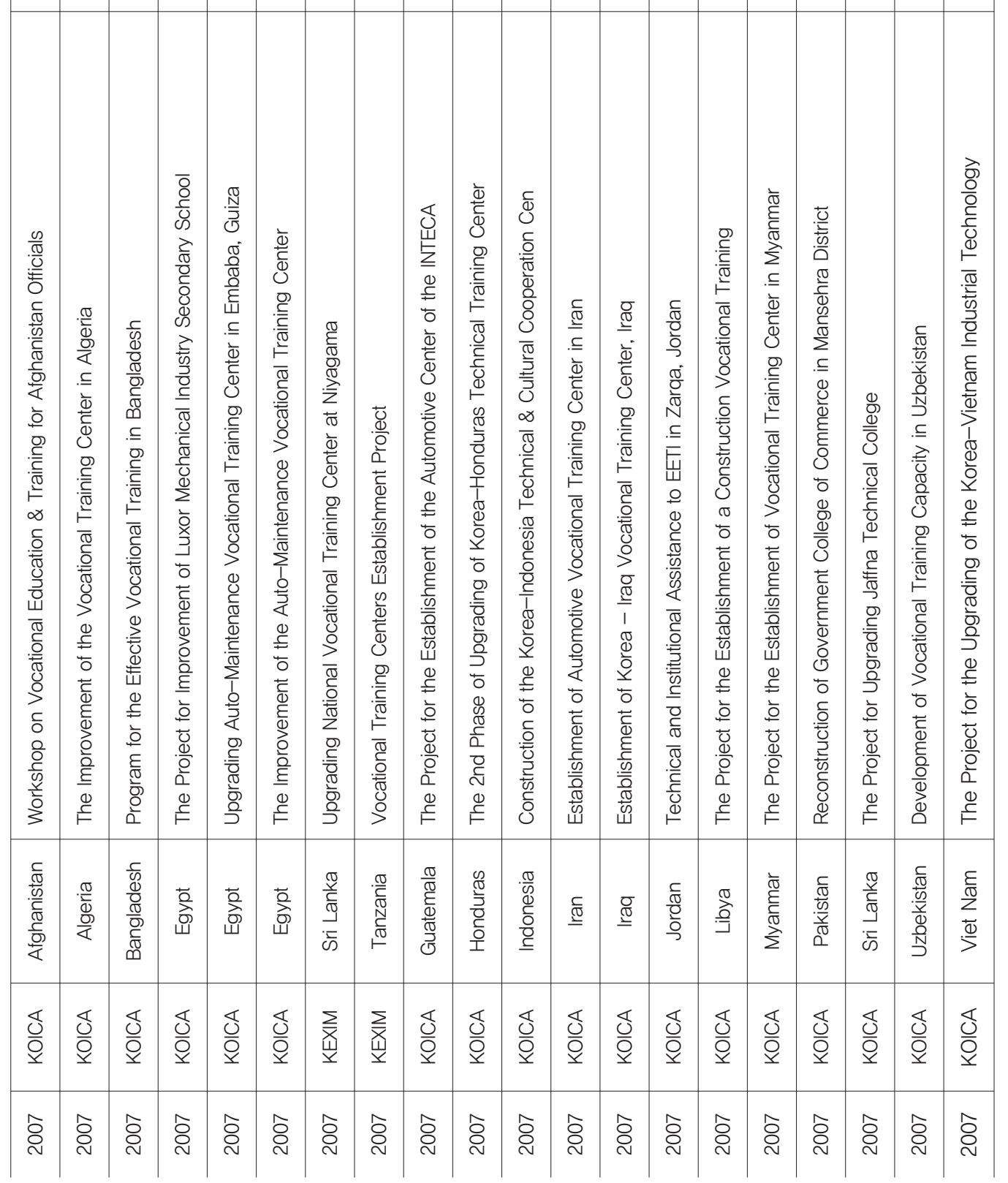




\begin{tabular}{|c|c|c|c|c|c|c|c|c|c|c|c|c|c|c|c|}
\hline$\stackrel{\mathcal{O}}{\sum}$ & $\begin{array}{l}\text { y } \\
\text { O }\end{array}$ & 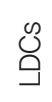 & $\begin{array}{l}\mathcal{y} \\
\text { O }\end{array}$ & 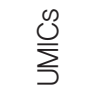 & $\stackrel{\mathscr{S}}{\sum}$ & $\stackrel{\mathcal{S}}{\sum}$ & $\stackrel{\mathcal{N}}{\sum}$ & $\stackrel{\mathcal{N}}{\sum}$ & $\stackrel{\mathcal{O}}{\sum}$ & $\stackrel{\mathcal{S}}{\sum}$ & $\begin{array}{l}\text { Ò } \\
\text { O }\end{array}$ & 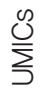 & $\frac{\mathcal{O}}{\sum_{\supset}}$ & 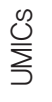 & 岁 \\
\hline 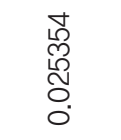 & $\begin{array}{l}\text { U్ } \\
\text { ऽ̊ } \\
\text { Oे. } \\
0\end{array}$ & 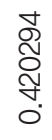 & 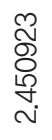 & 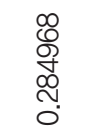 & 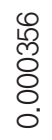 & $\begin{array}{l}\hat{2} \\
\text { के } \\
\text { ल. } \\
0\end{array}$ & 䞘 & $\begin{array}{l}\text { 苋 } \\
\stackrel{\mathrm{N}}{\mathrm{N}} \\
0\end{array}$ & 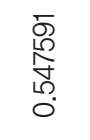 & $\begin{array}{l}\text { ठ } \\
\infty \\
\text { Oे } \\
\text { ले. } \\
6\end{array}$ & 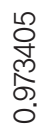 & 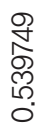 & 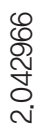 & $\begin{array}{l}\text { న్ } \\
\text { సิ } \\
\text { م. } \\
0 .\end{array}$ & 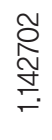 \\
\hline 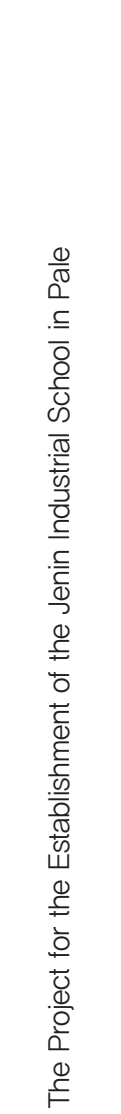 & 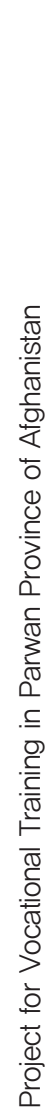 & 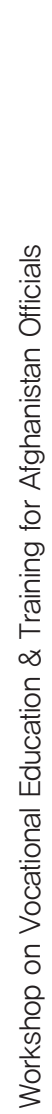 & 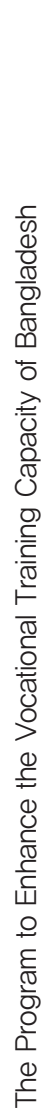 & 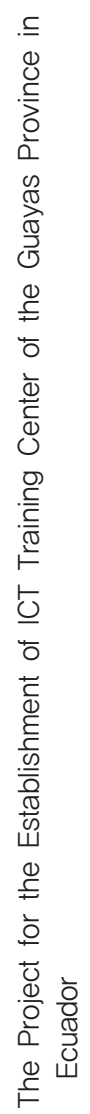 & 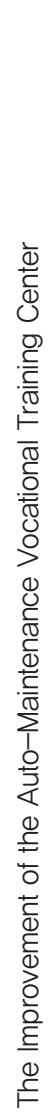 & 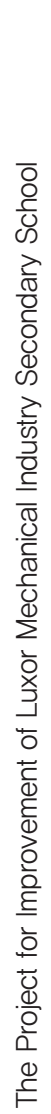 & 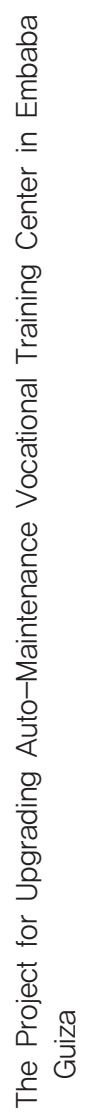 & 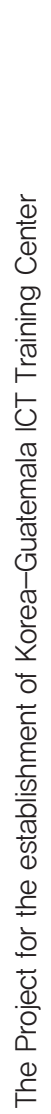 & 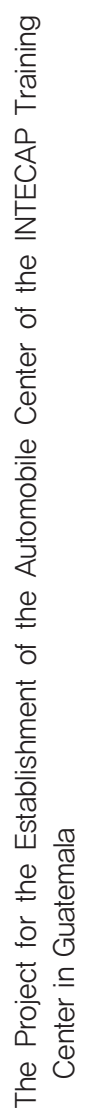 & 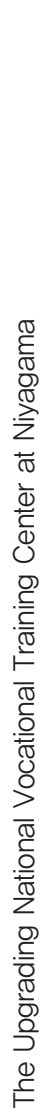 & 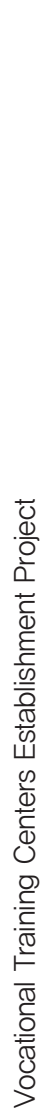 & 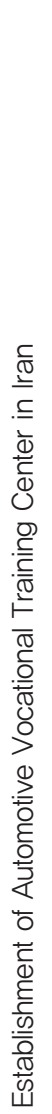 & 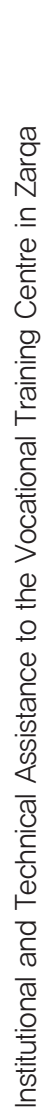 & 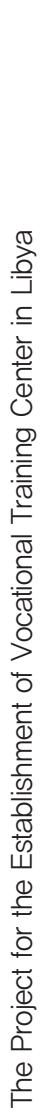 & 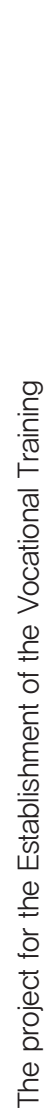 \\
\hline 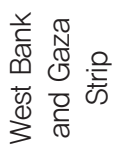 & 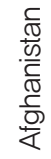 & 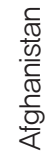 & $\begin{array}{l}\frac{c}{w} \\
\frac{1}{0} \\
\frac{\mathbb{D}}{0} \\
\mathbb{D} \\
\mathbb{D} \\
\mathbb{D}\end{array}$ & 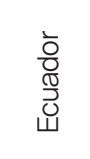 & 䓂 & 䓂 & 蒿 & $\begin{array}{l}\frac{\pi}{\mathbb{N}} \\
\frac{E}{0} \\
\frac{\mathbb{D}}{\pi} \\
\frac{D}{0}\end{array}$ & 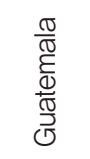 & 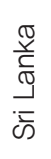 & 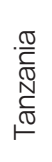 & 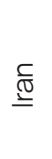 & $\begin{array}{l}\text { 주 } \\
\text { 잉 } \\
\mathcal{g}\end{array}$ & 苞 & 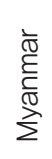 \\
\hline $\begin{array}{l}\frac{x}{0} \\
\frac{0}{0} \\
\underline{y}\end{array}$ & $\begin{array}{l}\overleftarrow{J} \\
\bar{O} \\
\underline{X}\end{array}$ & $\begin{array}{l}\overleftarrow{\delta} \\
\frac{\mathbb{O}}{\mathrm{O}} \\
\end{array}$ & $\begin{array}{l}\text { đ } \\
\frac{0}{O} \\
\underline{y}\end{array}$ & $\begin{array}{l}\frac{1}{0} \\
\frac{0}{O} \\
\underline{y}\end{array}$ & 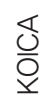 & $\begin{array}{l}\mathbb{U} \\
\frac{0}{O} \\
\underline{y}\end{array}$ & $\begin{array}{l}\frac{\mathbb{U}}{0} \\
\stackrel{0}{O}\end{array}$ & $\begin{array}{l}\frac{\mathbb{U}}{0} \\
\frac{0}{0}\end{array}$ & $\begin{array}{l}\frac{\pi}{0} \\
\frac{0}{O}\end{array}$ & 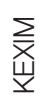 & 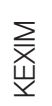 & 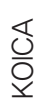 & $\begin{array}{l}\frac{\mathbb{u}}{0} \\
\overline{0}\end{array}$ & 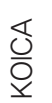 & 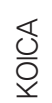 \\
\hline ঠి & $\stackrel{\infty}{0}$ & $\stackrel{\infty}{0}$ & $\begin{array}{l}\infty \\
\stackrel{\sim}{0}\end{array}$ & $\begin{array}{l}\infty \\
\text { ¿ }\end{array}$ & ¿ & 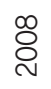 & $\begin{array}{l}\infty \\
\stackrel{\sim}{0}\end{array}$ & 曲 & $\begin{array}{l}\infty \\
\stackrel{\sim}{0}\end{array}$ & $\begin{array}{l}\infty \\
\stackrel{\sim}{0}\end{array}$ & $\begin{array}{l}\infty \\
\stackrel{\sim}{\alpha}\end{array}$ & $\begin{array}{l}\infty \\
\stackrel{\sim}{\sim}\end{array}$ & ฉ & $\underset{\sim}{\infty}$ & 完 \\
\hline
\end{tabular}




\begin{tabular}{|c|c|c|c|c|c|c|c|c|c|c|c|c|c|c|c|c|}
\hline $\begin{array}{l}\text { O } \\
\text { O }\end{array}$ & $\stackrel{\mathcal{N}}{\sum}$ & $\stackrel{\mathscr{S}}{\sum}$ & $\stackrel{\mathcal{O}}{\sum}$ & 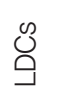 & $\begin{array}{l}\text { O } \\
\text { O }\end{array}$ & $\stackrel{\mathcal{S}}{\sum}$ & $\stackrel{\mathcal{S}}{\sum}$ & 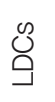 & $\stackrel{\mathcal{O}}{ٍ}$ & $\begin{array}{l}\infty \\
\text { Ò } \\
\end{array}$ & 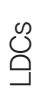 & $\stackrel{\mathcal{U}}{\sum}$ & $\stackrel{\mathcal{O}}{\sum}$ & $\begin{array}{l}\text { On } \\
\text { O }\end{array}$ & $\stackrel{\mathcal{S}}{\sum}$ & $\stackrel{\mathcal{S}}{\sum}$ \\
\hline 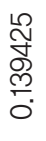 & 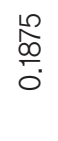 & $\begin{array}{l}\stackrel{\infty}{\simeq} \\
\stackrel{\infty}{\sim} \\
\stackrel{N}{=}\end{array}$ & $\begin{array}{l}\text { O్ } \\
\text { స్ } \\
\infty \\
0 \\
0\end{array}$ & $\begin{array}{l}\stackrel{\hat{ٌ}}{\sim} \\
\stackrel{\sim}{\circlearrowleft} \\
\stackrel{+}{+}\end{array}$ & 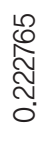 & 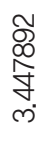 & 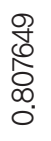 & 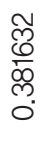 & $\begin{array}{l}\bar{y} \\
\text { ¿م } \\
\infty \\
0 \\
0\end{array}$ & 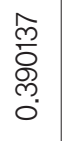 & 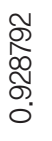 & 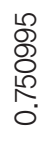 & 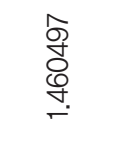 & 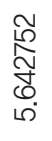 & 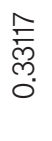 & 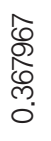 \\
\hline 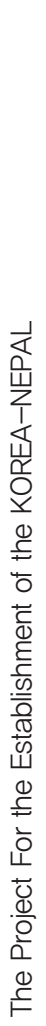 & 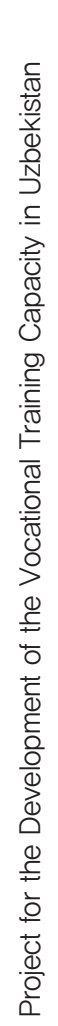 & 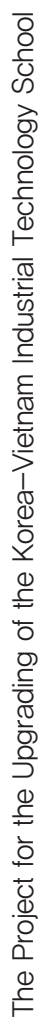 & 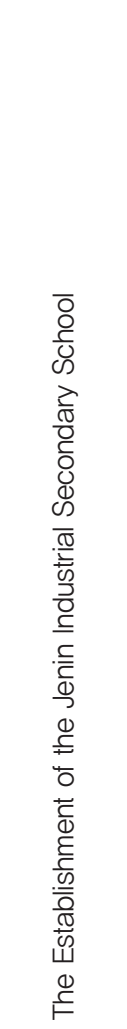 & 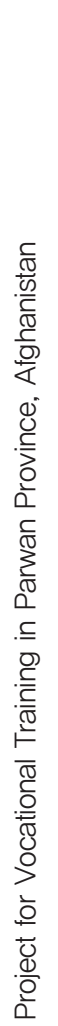 & 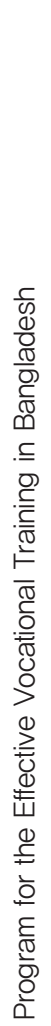 & 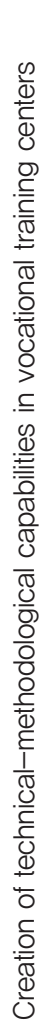 & 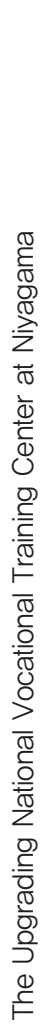 & 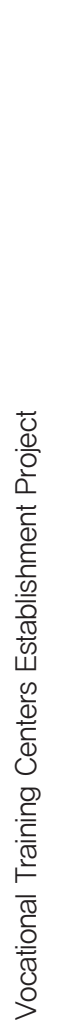 & 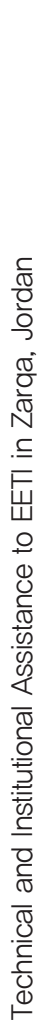 & 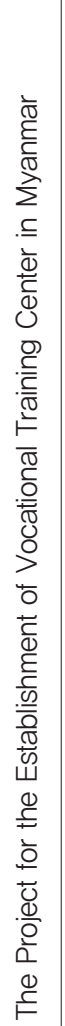 & 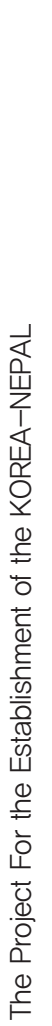 & 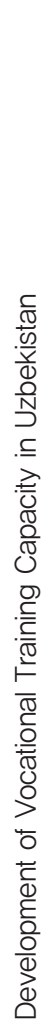 & 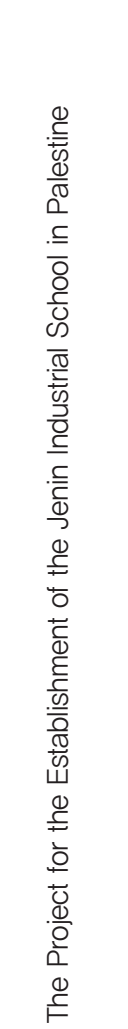 & 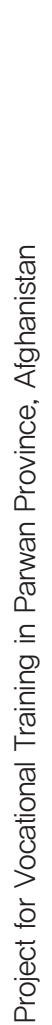 & 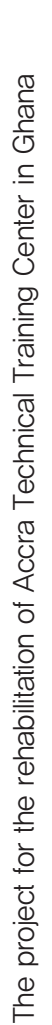 & 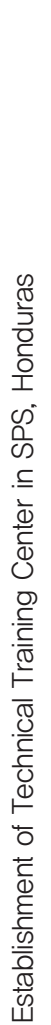 \\
\hline $\begin{array}{l}\overline{\mathbb{d}} \\
\frac{\mathrm{d}}{2}\end{array}$ & 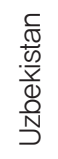 & 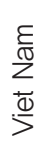 & 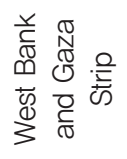 & 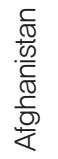 & $\begin{array}{l}\frac{c}{0} \\
\frac{1}{0} \\
\frac{\mathbb{D}}{0} \\
\frac{D}{\mathbb{D}} \\
\mathbb{D}\end{array}$ & $\begin{array}{l}\frac{\pi}{\sigma} \\
\frac{\pi}{0} \\
\frac{\pi}{\pi} \\
\frac{0}{2}\end{array}$ & 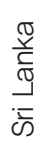 & 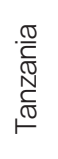 & 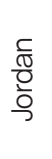 & $\begin{array}{l}\overline{\bar{\sigma}} \\
\stackrel{\bar{E}}{\bar{\sigma}} \\
\stackrel{\nabla}{\Sigma}\end{array}$ & $\begin{array}{l}\overline{\bar{\alpha}} \\
\frac{0}{0}\end{array}$ & 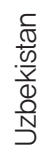 & 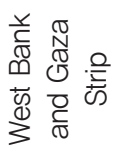 & 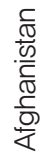 & $\begin{array}{l}\frac{\mathbb{V}}{\mathbb{V}} \\
\frac{\mathbb{V}}{\mathbb{N}}\end{array}$ & 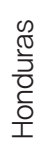 \\
\hline $\begin{array}{l}\frac{1}{0} \\
\frac{0}{O}\end{array}$ & 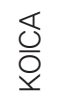 & $\begin{array}{l}\frac{1}{\delta} \\
\frac{0}{O} \\
\underline{x}\end{array}$ & $\begin{array}{l}\frac{1}{0} \\
\frac{0}{O} \\
\underline{x}\end{array}$ & $\begin{array}{l}\frac{\pi}{0} \\
\frac{0}{0} \\
\frac{1}{2}\end{array}$ & $\begin{array}{l}\frac{\pi}{\delta} \\
\frac{0}{0} \\
\underline{y}\end{array}$ & 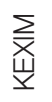 & 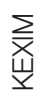 & 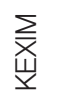 & $\begin{array}{l}\frac{1}{0} \\
\frac{0}{0} \\
\underline{x}\end{array}$ & $\begin{array}{l}\overleftarrow{J} \\
\bar{O} \\
\underline{y}\end{array}$ & $\begin{array}{l}\overleftarrow{\Delta} \\
\frac{0}{\partial} \\
\underline{y}\end{array}$ & $\begin{array}{l}\frac{1}{0} \\
\frac{0}{0} \\
\underline{y}\end{array}$ & $\begin{array}{l}\frac{1}{0} \\
\frac{0}{0} \\
\underline{y}\end{array}$ & $\begin{array}{l}\frac{1}{0} \\
\frac{0}{0} \\
\underline{y}\end{array}$ & $\begin{array}{l}\frac{\pi}{0} \\
\frac{0}{O}\end{array}$ & $\begin{array}{l}\frac{\pi}{\delta} \\
\frac{0}{O} \\
\underline{y}\end{array}$ \\
\hline $\begin{array}{l}\infty \\
\stackrel{人}{0}\end{array}$ & $\begin{array}{l}\infty \\
\stackrel{0}{0}\end{array}$ & $\begin{array}{l}\infty \\
\stackrel{\sim}{\sim}\end{array}$ & $\begin{array}{l}\infty \\
\stackrel{0}{0}\end{array}$ & : & ஜ) & 尺 & ஜ) & ¿ & ஜे & ஜे & ஜ & ஜे & ஜ) & 음 & 윰 & 윰 \\
\hline
\end{tabular}




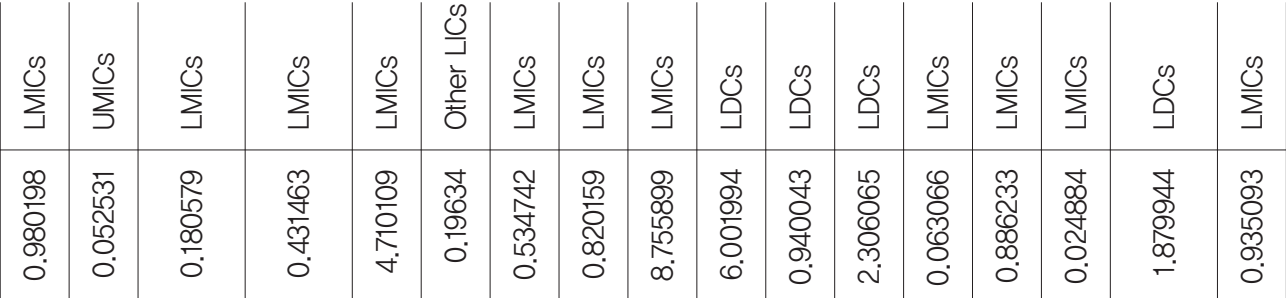

\begin{tabular}{|c|c|c|c|c|c|c|c|c|c|c|c|c|c|c|c|c|}
\hline 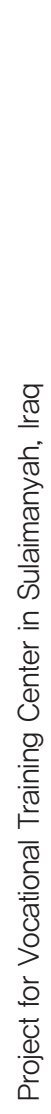 & 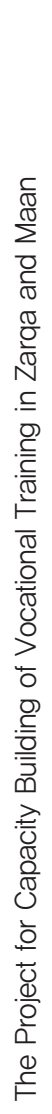 & 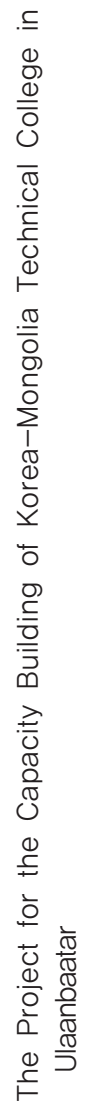 & 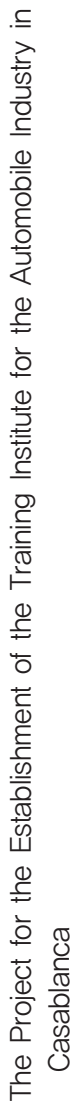 & 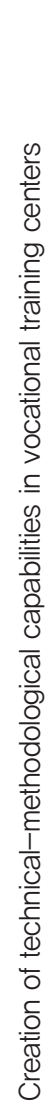 & 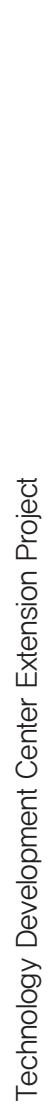 & 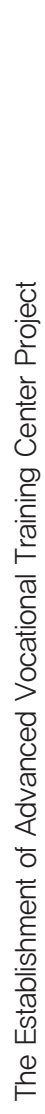 & 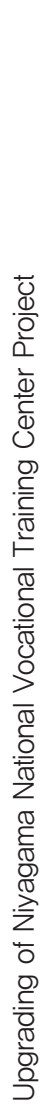 & 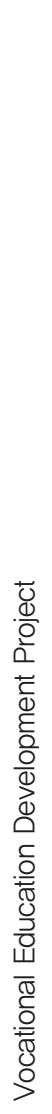 & 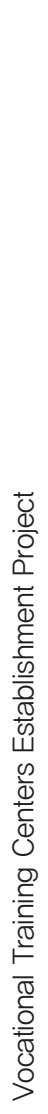 & 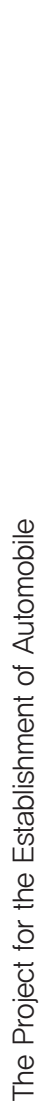 & 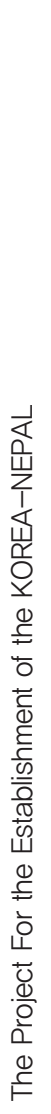 & 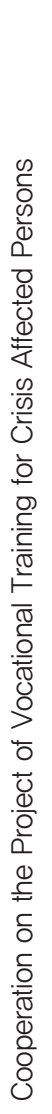 & 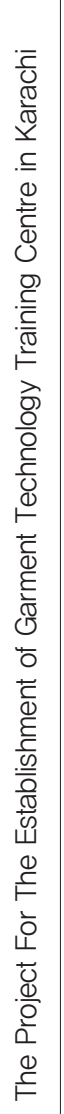 & 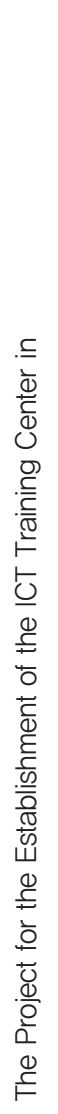 & 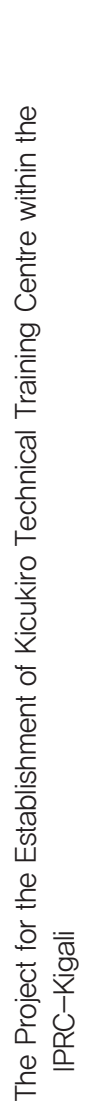 & 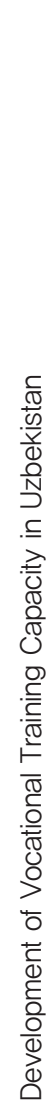 \\
\hline 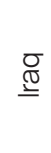 & $\begin{array}{l}\frac{c}{0} \\
\frac{0}{0} \\
\text { 익 }\end{array}$ & $\begin{array}{l}\frac{\underline{\underline{D}}}{\bar{O}} \\
\overline{\mathrm{g}} \\
\overline{0} \\
\Sigma\end{array}$ & 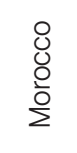 & 苞 & 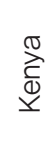 & 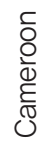 & $\frac{\sqrt[\pi]{2}}{\underset{\mathbb{N}}{\mathbb{N}}}$ & 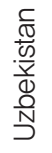 & 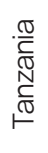 & 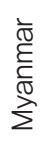 & $\begin{array}{l}\overline{\overline{0}} \\
\frac{0}{2}\end{array}$ & 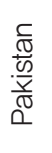 & 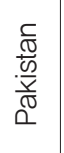 & 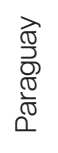 & 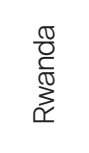 & $\begin{array}{l}\frac{1}{\pi} \\
\frac{\pi}{0} \\
\frac{D}{D} \\
\frac{D}{D}\end{array}$ \\
\hline $\begin{array}{l}\overleftarrow{J} \\
\stackrel{0}{O} \\
\stackrel{y}{*}\end{array}$ & $\begin{array}{l}\overleftarrow{J} \\
\frac{0}{0} \\
\underline{y}\end{array}$ & 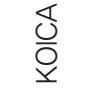 & 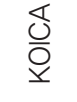 & 岗 & 刹 & 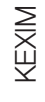 & צ & 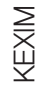 & $x$ & $\begin{array}{l}\overleftarrow{J} \\
\frac{0}{O} \\
\stackrel{y}{0}\end{array}$ & 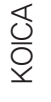 & $\begin{array}{l}\frac{1}{0} \\
\frac{0}{O} \\
\underline{y}\end{array}$ & $\begin{array}{l}\overleftarrow{U} \\
\frac{0}{0} \\
\underline{y}\end{array}$ & $\begin{array}{l}\mathbb{J} \\
\frac{0}{0} \\
\frac{1}{1}\end{array}$ & 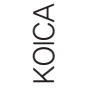 & 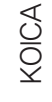 \\
\hline $\bar{\sigma}$ & 음 & 음 & 음 & $\sim$ & & $\dot{\sim}$ & ని & $\overline{\mathcal{D}}$ & & $\bar{\sim}$ & ¿ & $\bar{\sim}$ & 음 & 尺 & 음 & ָ \\
\hline
\end{tabular}




\begin{tabular}{|c|c|c|c|c|c|c|c|c|c|c|c|c|c|c|c|c|}
\hline$\stackrel{\mathscr{N}}{\sum}$ & $\stackrel{\mathcal{U}}{\sum}$ & $\sum_{j}^{\mathcal{O}}$ & 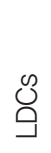 & 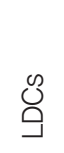 & $\sum_{3}^{\mathcal{O}}$ & $\stackrel{\mathcal{O}}{\sum}$ & $\stackrel{\mathcal{S}}{\sum}$ & $\sum_{3}^{\mathcal{O}}$ & $\sum_{3}^{\mathcal{U}}$ & $\sum_{3}^{\mathcal{O}}$ & 号 & $\begin{array}{l}\infty \\
\text { Oֵ } \\
\end{array}$ & 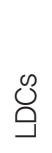 & 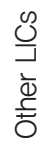 & $\stackrel{\mathcal{O}}{\sum}$ & $\stackrel{\mathcal{N}}{\sum}$ \\
\hline $\begin{array}{l}\hat{D} \\
\text { Оิ } \\
\text { O. } \\
\text { O. }\end{array}$ & $\begin{array}{l}\text { 尺্ } \\
\text { N̊ } \\
\stackrel{0}{0}\end{array}$ & $\begin{array}{l}\text { 尺े } \\
\text { 응 } \\
\text { ○. }\end{array}$ & $\underset{\substack{\infty \\
\stackrel{\infty}{N}}}{\stackrel{\infty}{\sim}}$ & $\begin{array}{l}\text { হ } \\
\text { Oे } \\
\text { ஒ. } \\
0\end{array}$ & \begin{tabular}{l} 
g. \\
ठ \\
\multirow{2}{*}{} \\
0
\end{tabular} & 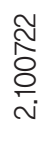 & 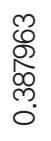 & 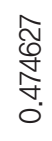 & $\begin{array}{l}\bar{\Phi} \\
\infty \\
0 \\
\\
0\end{array}$ & $\begin{array}{l}\text { N } \\
\text { N } \\
\stackrel{N}{N} \\
\stackrel{N}{N}\end{array}$ & & 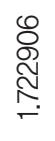 & 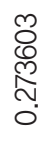 & $\begin{array}{l}\hat{0} \\
\frac{\$}{\Phi} \\
\infty \\
\dot{\infty}\end{array}$ & $\begin{array}{l}\stackrel{m}{+} \\
\infty \\
\stackrel{\infty}{\infty} \\
\stackrel{m}{m}\end{array}$ & $\begin{array}{l}\hat{\Omega} \\
\hat{L} \\
\stackrel{0}{0} \\
0\end{array}$ \\
\hline 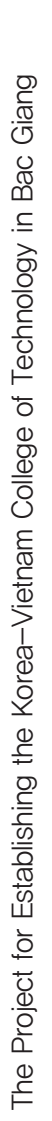 & 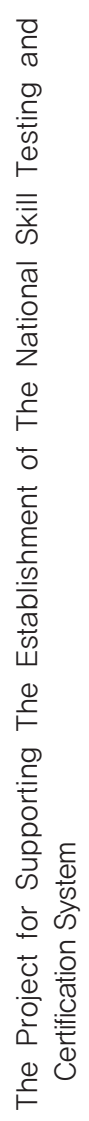 & 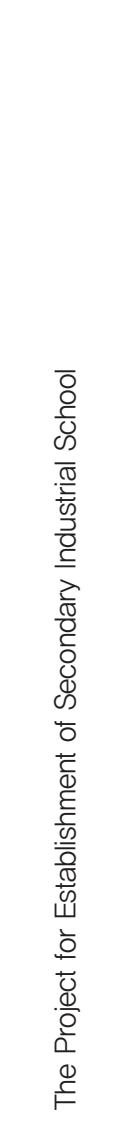 & 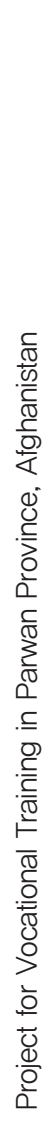 & 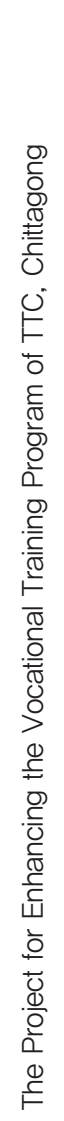 & 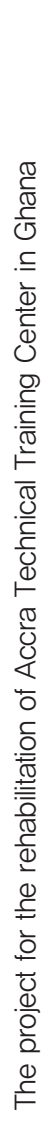 & 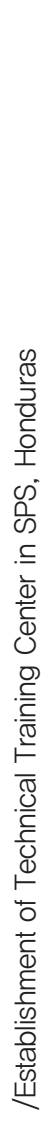 & 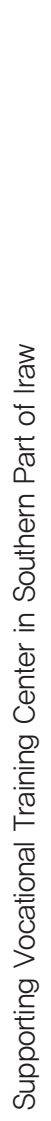 & 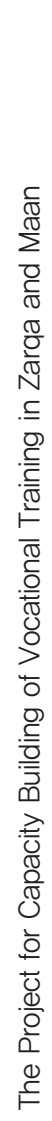 & 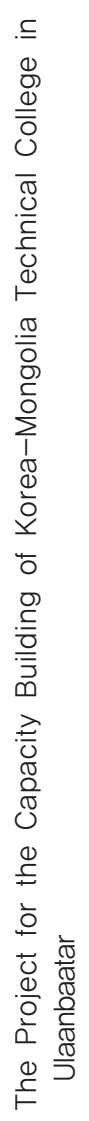 & 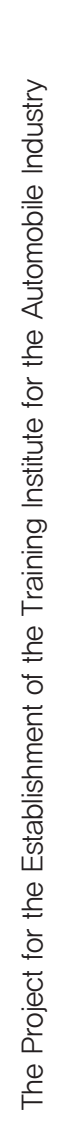 & 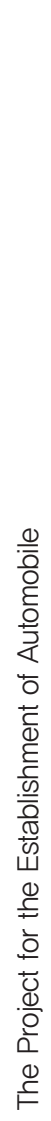 & 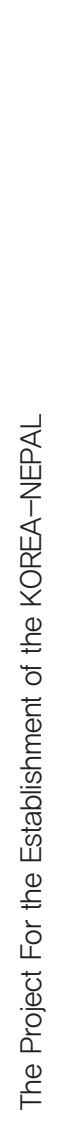 & 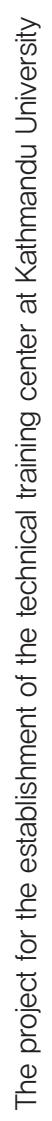 & 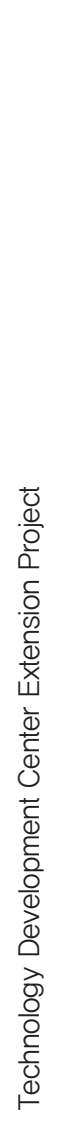 & 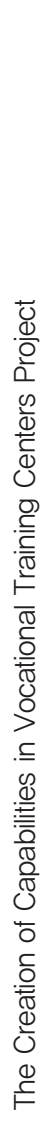 & 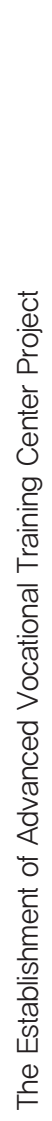 \\
\hline 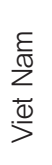 & $\begin{array}{l}\frac{E}{N} \\
Z \\
\frac{\mathbb{d}}{J}\end{array}$ & 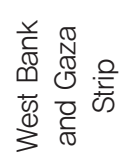 & 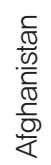 & $\begin{array}{l}\frac{c}{\Phi} \\
\frac{0}{D} \\
\frac{\mathbb{D}}{D} \\
\frac{\mathbb{D}}{\mathbb{D}}\end{array}$ & $\begin{array}{l}\frac{\pi}{\mathbb{N}} \\
\frac{\mathbb{N}}{\mathbb{N}}\end{array}$ & $\begin{array}{l}00 \\
\overparen{N} \\
\stackrel{0}{7} \\
\text { ㅇ } \\
\text { 오 }\end{array}$ & $\stackrel{\mathbb{\widetilde { \sigma }}}{\underline{\underline{\mathbb{\pi}}}}$ & $\begin{array}{l}\frac{}{0} \\
\text { 힘 }\end{array}$ & $\begin{array}{l}\frac{0}{\overline{0}} \\
\overline{0} \\
\frac{0}{2} \\
\frac{0}{2}\end{array}$ & $\begin{array}{l}8 \\
\text { O } \\
\text { 히 }\end{array}$ & 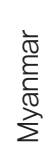 & $\begin{array}{l}\bar{\alpha} \\
\frac{0}{2}\end{array}$ & $\begin{array}{l}\overline{\mathbb{Q}} \\
\frac{\mathrm{d}}{2}\end{array}$ & $\begin{array}{l}\stackrel{\sigma}{\overparen{Q}} \\
\stackrel{Q}{\mathscr{Q}}\end{array}$ & $\begin{array}{l}\frac{\pi}{\sqrt{0}} \\
\text { D } \\
\frac{\mathbb{N}}{\mathbb{N}} \\
\frac{\mathrm{U}}{Z}\end{array}$ & 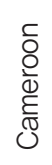 \\
\hline $\begin{array}{l}\frac{x}{0} \\
\frac{0}{O} \\
\frac{y}{4}\end{array}$ & $\begin{array}{l}\frac{1}{0} \\
\frac{0}{0}\end{array}$ & $\begin{array}{l}\frac{1}{0} \\
\frac{0}{0} \\
\underline{x}\end{array}$ & $\begin{array}{l}\frac{1}{0} \\
\frac{0}{O}\end{array}$ & $\begin{array}{l}\frac{\mathbb{U}}{0} \\
\frac{0}{2}\end{array}$ & $\begin{array}{l}\frac{1}{0} \\
\frac{0}{O} \\
\underline{y}\end{array}$ & $\begin{array}{l}\frac{x}{0} \\
\frac{0}{O} \\
\underline{y}\end{array}$ & $\begin{array}{l}\frac{\pi}{0} \\
\frac{0}{O}\end{array}$ & 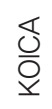 & $\begin{array}{l}\frac{1}{0} \\
\frac{0}{O} \\
\underline{y}\end{array}$ & $\begin{array}{l}\text { J } \\
\bar{O} \\
\underline{y}\end{array}$ & 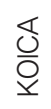 & $\begin{array}{l}\frac{\mathbb{J}}{0} \\
\overline{0} \\
\underline{y}\end{array}$ & $\begin{array}{l}\frac{1}{0} \\
\frac{0}{O} \\
\underline{y}\end{array}$ & 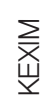 & $\underset{⿱ 亠 凶}{\stackrel{⿱ 亠 乂}{x}}$ & 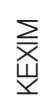 \\
\hline 음 & 응 & 음 & 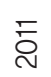 & $\bar{\delta}$ & ฉి & ని & ని & N & $\stackrel{\sim}{ }$ & ㄱ & ¿ & ¿ & ¿ి & ํ. & 尺 & $\stackrel{\sim}{ }$ \\
\hline
\end{tabular}




\begin{tabular}{|c|c|c|c|c|c|c|c|c|c|c|c|c|c|c|c|}
\hline$\stackrel{\mathcal{N}}{\sum}$ & $\stackrel{\mathcal{N}}{\sum}$ & 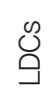 & $\stackrel{\mathcal{S}}{\sum}$ & $\stackrel{\mathscr{S}}{\sum}$ & 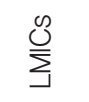 & $\stackrel{\mathcal{J}}{\sum}$ & $\stackrel{\mathcal{U}}{\sum}$ & 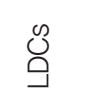 & $\begin{array}{l}\text { on } \\
\text { Oे }\end{array}$ & $\stackrel{\mathcal{O}}{\sum}$ & $\stackrel{\mathscr{S}}{\sum}$ & $\stackrel{\mathcal{S}}{\sum}$ & $\sum_{\Sigma}^{\mathcal{O}}$ & $\sum_{\Sigma}^{\infty}$ & 号 \\
\hline 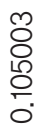 & 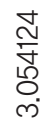 & $\begin{array}{l}\bar{\delta} \\
\text { o } \\
\bar{\delta} \\
\text { i }\end{array}$ & 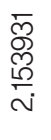 & $\begin{array}{l}\mathscr{P} \\
\stackrel{0}{0} \\
\infty \\
0 \\
0 \\
\stackrel{N}{N}\end{array}$ & 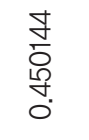 & $\begin{array}{l}\text { N } \\
\stackrel{N}{N} \\
0 \\
0\end{array}$ & $\begin{array}{l}\mathscr{\prod} \\
0 \\
\\
\circ \\
0\end{array}$ & 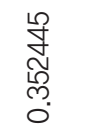 & $\begin{array}{l}0 \\
2 \\
\infty \\
\infty \\
N \\
0\end{array}$ & 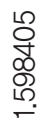 & 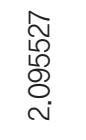 & 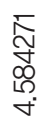 & $\begin{array}{l}\infty \\
\stackrel{\circ}{\circ} \\
\text { O্ঠ் } \\
\text { ○. }\end{array}$ & 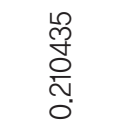 & 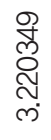 \\
\hline 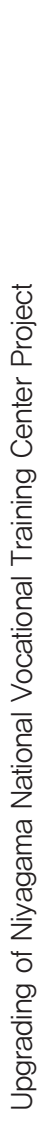 & 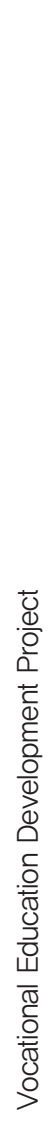 & 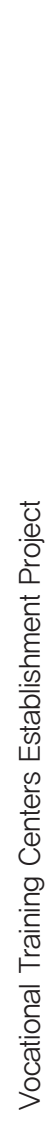 & 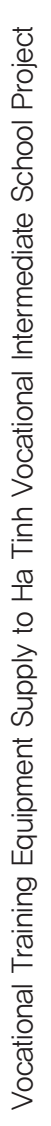 & 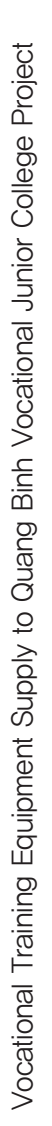 & 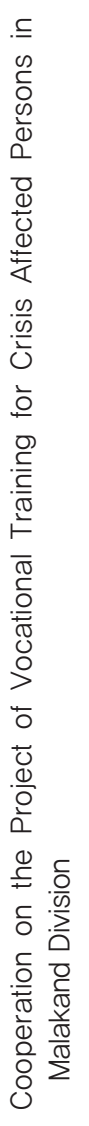 & 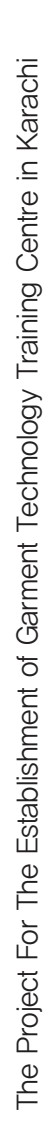 & 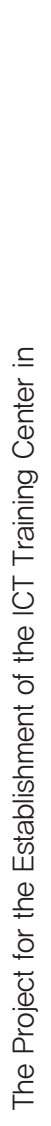 & 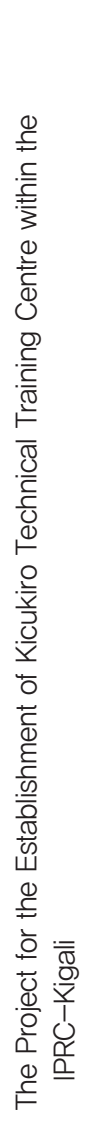 & 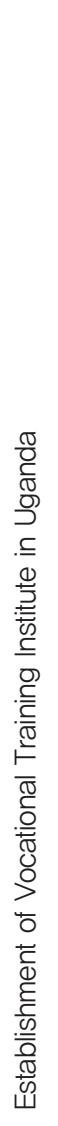 & 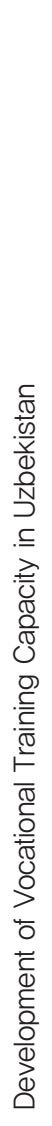 & 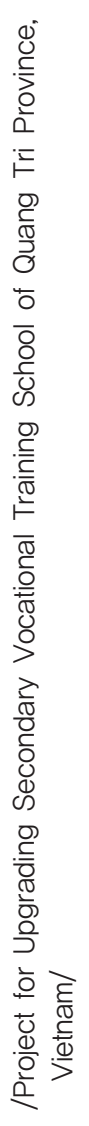 & 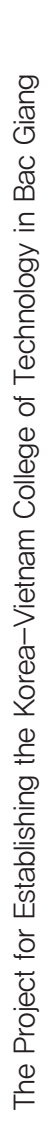 & 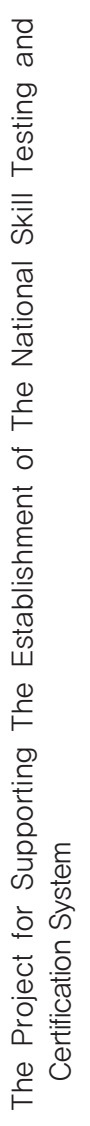 & 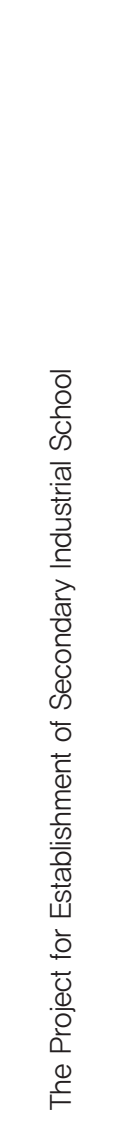 & 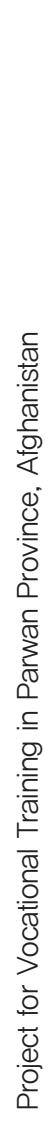 \\
\hline 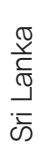 & $\begin{array}{l}\frac{c}{0} \\
\frac{d}{.0} \\
\frac{D}{D} \\
\frac{D}{N}\end{array}$ & $\begin{array}{l}\frac{\pi}{C} \\
\frac{\mathbb{N}}{\sqrt[N]{N}} \\
\stackrel{\mathbb{N}}{\sigma} \\
\vdash\end{array}$ & 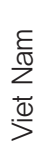 & 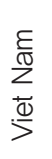 & 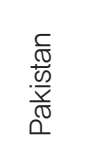 & 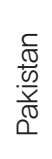 & $\begin{array}{l}\frac{\pi}{0} \\
\frac{0}{0} \\
\frac{\pi}{\pi} \\
0\end{array}$ & $\begin{array}{l}\frac{\pi}{0} \\
\frac{\mathbb{N}}{\mathbb{N}} \\
\frac{\pi}{x}\end{array}$ & $\begin{array}{l}\frac{\pi}{0} \\
\frac{\mathbb{\sigma}}{\mathbb{N}} \\
\text { S }\end{array}$ & 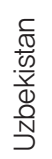 & 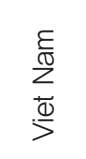 & 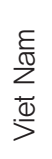 & $\begin{array}{l}\frac{E}{\mathbb{N}} \\
\sum_{+}^{\frac{d}{j}}\end{array}$ & 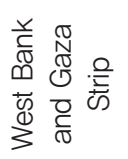 & $\begin{array}{l}\frac{c}{\pi} \\
\frac{\pi}{.01} \\
\frac{10}{\pi} \\
\frac{0}{0} \\
\frac{0}{4}\end{array}$ \\
\hline 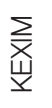 & $\begin{array}{l}\sum \\
\text { 离 }\end{array}$ & $\underset{\text { 岃 }}{\sum}$ & 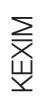 & 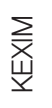 & $\begin{array}{l}\frac{1}{0} \\
\frac{0}{0} \\
\underline{x}\end{array}$ & 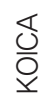 & $\begin{array}{l}\frac{\pi}{0} \\
\frac{0}{0}\end{array}$ & $\begin{array}{l}\frac{\pi}{0} \\
\frac{0}{0}\end{array}$ & 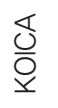 & $\begin{array}{l}\frac{\pi}{0} \\
\frac{0}{0}\end{array}$ & $\begin{array}{l}\frac{\pi}{0} \\
\frac{0}{0}\end{array}$ & $\begin{array}{l}\frac{1}{0} \\
\frac{0}{2}\end{array}$ & $\begin{array}{l}\frac{\pi}{0} \\
\frac{0}{0}\end{array}$ & $\begin{array}{l}\frac{1}{0} \\
\frac{0}{0}\end{array}$ & 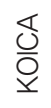 \\
\hline $\bar{\delta}$ & $\bar{\sigma}$ & $\bar{\delta}$ & $\bar{\sim}$ & ¿ & $\overline{\check{D}}$ & $\bar{\nabla}$ & ㅇ & $\bar{\sim}$ & $\stackrel{\sim}{ }$ & $\bar{尺}$ & $\bar{\sim}$ & $\stackrel{\sim}{ }$ & $\bar{\sigma}$ & $\overline{\check{D}}$ & $\stackrel{\widetilde{N}}{\bar{\nu}}$ \\
\hline
\end{tabular}




\begin{tabular}{|c|c|c|c|c|c|c|c|c|c|c|c|c|c|c|c|c|}
\hline 总 & $\sum_{3}^{\mathcal{U}}$ & 品 & $\sum_{\Sigma}^{\mathcal{U}}$ & $\sum_{\Sigma}^{\mathcal{O}}$ & $\sum_{\Sigma}^{\mathcal{U}}$ & $\sum_{3}^{\mathcal{U}}$ & $\mathcal{N}_{\Sigma}^{\mathcal{N}}$ & $\sum_{3}^{\mathcal{O}}$ & 号 & 品 & 号 & $\sum_{j}^{\mathcal{U}}$ & $\sum_{i}^{\mathcal{O}}$ & $\sum_{\Sigma}^{\mathcal{O}}$ & 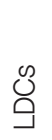 & $\begin{array}{l}\frac{\mathcal{O}}{J} \\
\bar{\Phi} \\
\stackrel{ \pm}{0}\end{array}$ \\
\hline 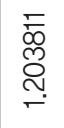 & 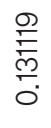 & 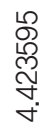 & 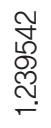 & $\begin{array}{l}\stackrel{J}{~} \\
\text { O্ষি } \\
\stackrel{-}{-}\end{array}$ & $\begin{array}{l}\frac{10}{6} \\
\frac{0}{0} \\
\end{array}$ & $\begin{array}{l}\infty \\
\mathbb{1} \\
\mathscr{8} \\
\infty \\
0\end{array}$ & $\begin{array}{l}\text { D } \\
\text { D. } \\
0 \\
0\end{array}$ & $\begin{array}{l}\text { d } \\
8 \\
8 \\
\infty \\
\text { N }\end{array}$ & 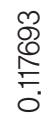 & 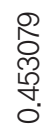 & 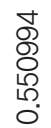 & $\begin{array}{l}\text { ల్ } \\
\text { ర్ } \\
\stackrel{\text { v. }}{0}\end{array}$ & 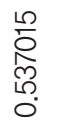 & 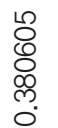 & $\begin{array}{l}\text { ల్ } \\
\text { ల్ర } \\
\text { O. }\end{array}$ & $\begin{array}{l}\bar{c} \\
\text { ल } \\
\infty \\
\text { m. }\end{array}$ \\
\hline
\end{tabular}

\begin{tabular}{|c|c|c|c|c|c|c|c|c|c|c|c|c|c|c|c|c|c|}
\hline 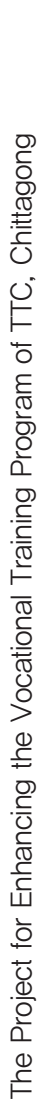 & 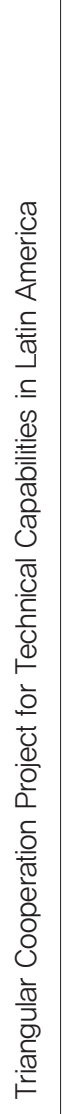 & 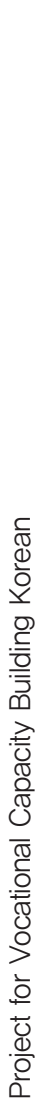 & 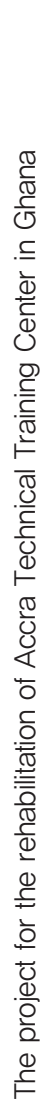 & 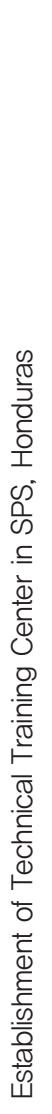 & 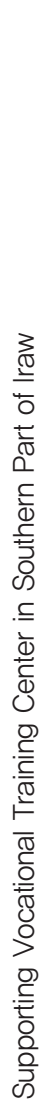 & 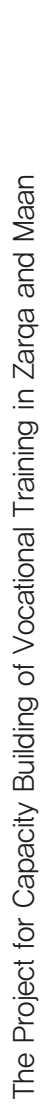 & 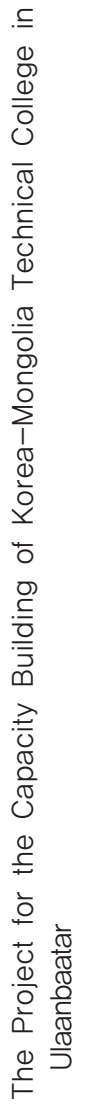 & 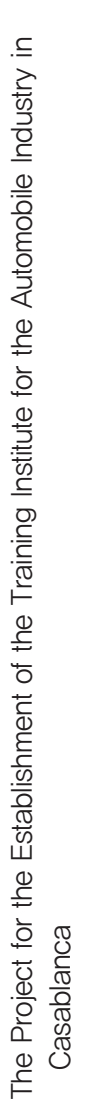 & 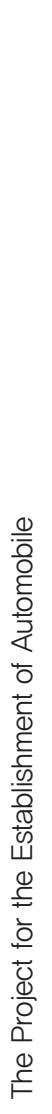 & 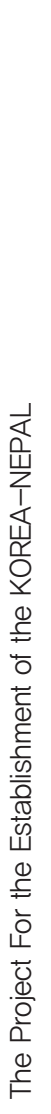 & 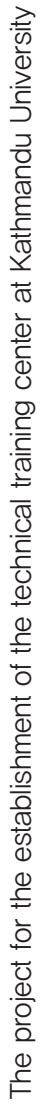 & 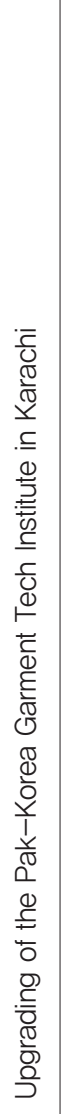 & 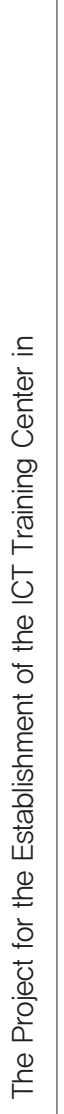 & 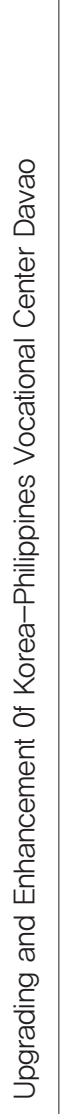 & 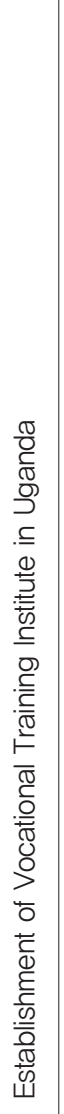 & 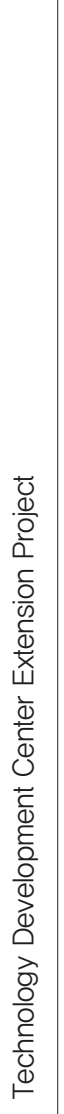 & 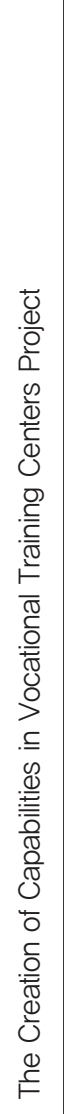 \\
\hline 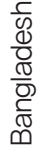 & 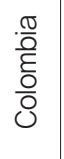 & 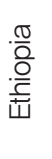 & $\begin{array}{l}\frac{\mathbb{O}}{\mathbb{V}} \\
\frac{\mathbb{V}}{\mathbb{N}}\end{array}$ & 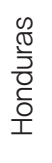 & $\underset{\underline{\widetilde{\sigma}}}{\underline{\widetilde{\sigma}}}$ & $\begin{array}{l}\frac{}{\mathbb{0}} \\
\text { 임 }\end{array}$ & 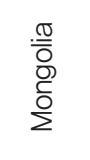 & 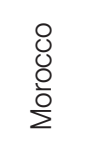 & 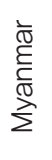 & $\begin{array}{l}\overline{\overline{0}} \\
\frac{0}{2}\end{array}$ & $\begin{array}{l}\overline{\widetilde{\Omega}} \\
\frac{\mathbb{Q}}{2}\end{array}$ & 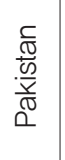 & $\begin{array}{l}\overrightarrow{\widehat{\sigma}} \\
\bar{\sigma} \\
\frac{\sigma}{\bar{\sigma}} \\
\alpha\end{array}$ & 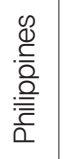 & $\begin{array}{l}\frac{\pi}{0} \\
\mathbb{\sigma} \\
\stackrel{\sigma}{\rho}\end{array}$ & $\begin{array}{l}\mathbb{0} \\
\stackrel{\vec{Q}}{\mathbb{Q}} \\
\underline{\underline{V}}\end{array}$ & $\begin{array}{l}\frac{\pi}{J} \\
\frac{D}{\pi} \\
\frac{\pi}{\pi} \\
\frac{U}{Z}\end{array}$ \\
\hline $\begin{array}{l}\frac{1}{0} \\
\frac{0}{0} \\
\stackrel{y}{y}\end{array}$ & 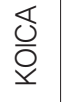 & $\begin{array}{l}\frac{1}{0} \\
\frac{0}{O} \\
\underline{y}\end{array}$ & $\begin{array}{l}\overleftarrow{J} \\
\frac{0}{0} \\
\stackrel{1}{y}\end{array}$ & $\begin{array}{l}\overleftarrow{y} \\
\stackrel{0}{O} \\
\stackrel{y}{y}\end{array}$ & $\begin{array}{l}\overleftarrow{J} \\
\frac{0}{0} \\
\stackrel{y}{0}\end{array}$ & $\begin{array}{l}\overleftarrow{J} \\
\frac{0}{0} \\
\stackrel{y}{0}\end{array}$ & 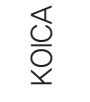 & $\begin{array}{l}\overleftarrow{J} \\
\stackrel{0}{0} \\
\stackrel{y}{0}\end{array}$ & 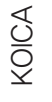 & $\begin{array}{l}\frac{1}{0} \\
\frac{0}{O} \\
\stackrel{y}{*}\end{array}$ & $\begin{array}{l}\frac{1}{0} \\
\frac{0}{0} \\
\underline{y}\end{array}$ & $\begin{array}{l}\overleftarrow{y} \\
\bar{O} \\
\stackrel{0}{1}\end{array}$ & $\begin{array}{l}\overleftarrow{J} \\
\stackrel{0}{0} \\
\stackrel{y}{x}\end{array}$ & $\begin{array}{l}\overleftarrow{J} \\
\frac{0}{0} \\
\stackrel{y}{0}\end{array}$ & $\begin{array}{l}\overleftarrow{y} \\
\frac{0}{0} \\
\stackrel{y}{0}\end{array}$ & $\underset{\underset{⿱ 亠 乂}{\longrightarrow}}{\sum}$ & 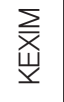 \\
\hline$\overline{\tilde{D}}$ & $\tilde{D}$ & $\bar{\Sigma}$ & ฉ & $\bar{N}$ & ㅇ & $\stackrel{\sim}{ }$ & $\frac{N}{2}$ & $\frac{\sim}{2}$ & $\stackrel{ }{\tilde{D}}$ & i & $\overline{\tilde{D}}$ & $\bar{\sim}$ & $\frac{N}{2}$ & $\stackrel{\sim}{\check{N}}$ & $\stackrel{\sim}{2}$ & Nㅜㅇ & 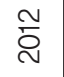 \\
\hline
\end{tabular}




\begin{tabular}{|c|c|c|c|c|c|c|c|c|c|c|c|c|c|c|c|c|}
\hline$\stackrel{\mathscr{N}}{\sum}$ & $\stackrel{\mathcal{N}}{\sum}$ & $\stackrel{\mathcal{N}}{\sum}$ & $\begin{array}{l}\text { y } \\
\text { D }\end{array}$ & $\stackrel{\mathcal{O}}{\sum}$ & $\stackrel{\mathcal{S}}{\sum}$ & $\stackrel{\mathscr{N}}{\sum}$ & $\stackrel{\mathcal{N}}{\sum}$ & $\stackrel{\mathcal{N}}{\sum}$ & $\stackrel{\mathcal{S}}{\sum}$ & $\stackrel{\mathcal{N}}{\sum}$ & $\stackrel{\mathcal{O}}{\sum}$ & $\begin{array}{l}\text { y } \\
\text { O }\end{array}$ & 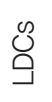 & 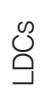 & 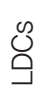 & $\stackrel{\mathscr{N}}{\sum}$ \\
\hline $\begin{array}{l}0 \\
\frac{1}{0} \\
\text { đั. } \\
\text { ․ }\end{array}$ & $\begin{array}{l}\infty \\
\text { Dे } \\
\infty \\
\text { o } \\
0 \\
0\end{array}$ & \begin{tabular}{l}
$\bar{y}$ \\
छ̊ \\
\multirow{7}{0}{} \\
0
\end{tabular} & 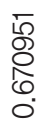 & 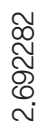 & $\begin{array}{l}\infty \\
\bar{\delta} \\
\infty \\
\infty \\
0 \\
0\end{array}$ & $\begin{array}{l}\text { O } \\
\infty \\
\mathbb{O} \\
\text { N } \\
0\end{array}$ & $\begin{array}{l}0 \\
\text { D } \\
\text { O̦ } \\
0\end{array}$ & 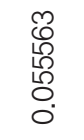 & $\begin{array}{l}\hat{0} \\
\hat{N} \\
0 \\
\stackrel{0}{0} \\
0\end{array}$ & $\begin{array}{l}0 \\
\stackrel{0}{0} \\
0 \\
0 \\
0 \\
0\end{array}$ & $\begin{array}{l}\infty \\
\stackrel{0}{f} \\
\infty \\
\stackrel{\infty}{\leftarrow}\end{array}$ & 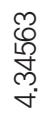 & 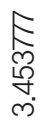 & $\begin{array}{l}\text { D্ } \\
\text { סे } \\
\text { O. } \\
\text {. }\end{array}$ & 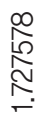 & $\begin{array}{l}\frac{\infty}{c 0} \\
\frac{0}{2} \\
0 \\
0 \\
0\end{array}$ \\
\hline 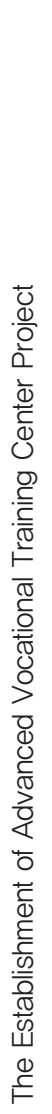 & 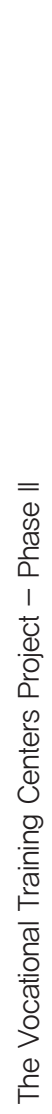 & 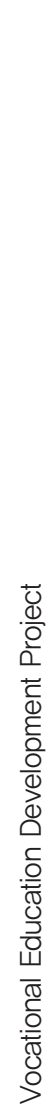 & 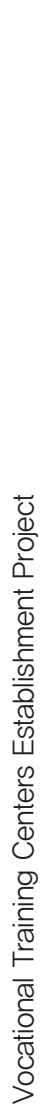 & 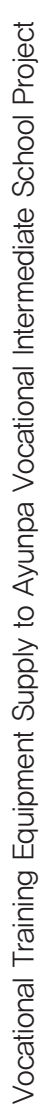 & 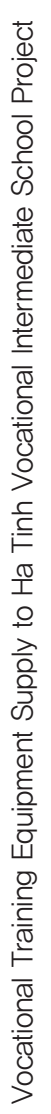 & 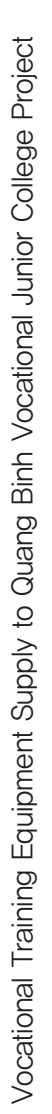 & 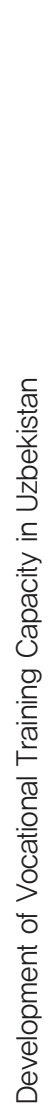 & 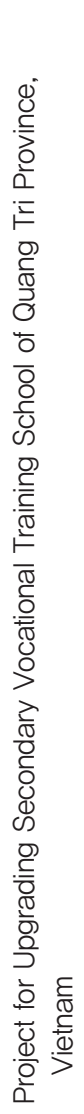 & 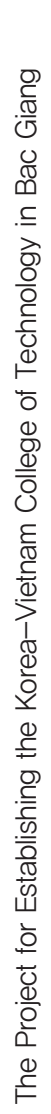 & 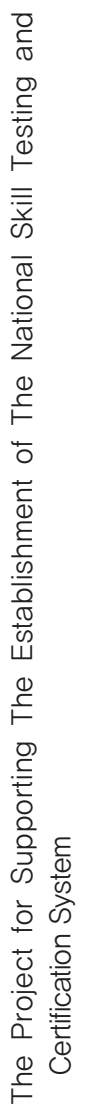 & 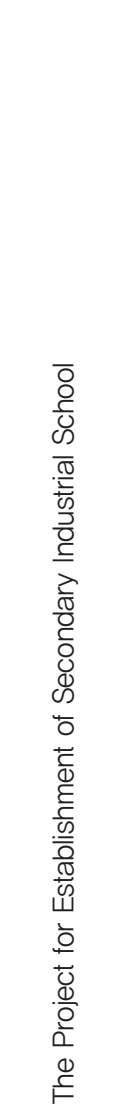 & 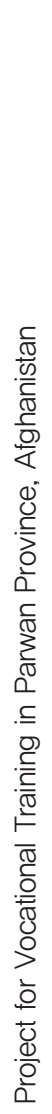 & 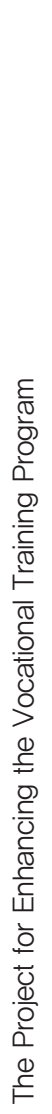 & 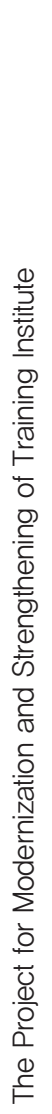 & 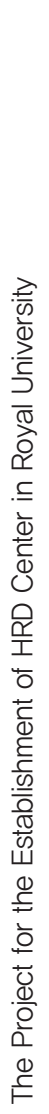 & 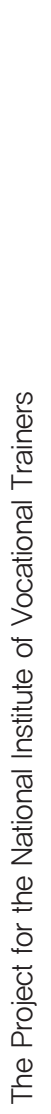 \\
\hline 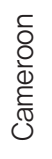 & $\begin{array}{l}\frac{\pi}{9} \\
\frac{\pi}{\sigma} \\
\frac{\pi}{\pi} \\
\frac{0}{2}\end{array}$ & 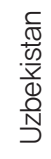 & 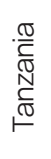 & 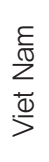 & 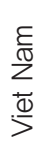 & 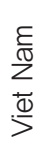 & $\begin{array}{l}\frac{\bar{N}}{\frac{\pi}{0 N}} \\
\frac{\mathrm{D}}{0} \\
\frac{0}{N}\end{array}$ & 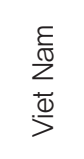 & $\begin{array}{l}\frac{E}{N} \\
\frac{N}{2} \\
j\end{array}$ & $\begin{array}{l}\frac{E}{\mathbb{N}} \\
\sum_{\mathbb{\Phi}}^{\underline{J}}\end{array}$ & 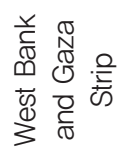 & 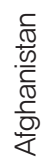 & $\begin{array}{l}\frac{1}{0} \\
\frac{0}{0} \\
\frac{0}{0} \\
\frac{\pi}{0} \\
\frac{\mathbb{D}}{0} \\
0\end{array}$ & 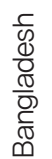 & 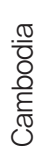 & 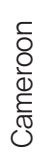 \\
\hline$\underset{⿱ 亠 凶}{\stackrel{⿱ 亠 乂}{x}}$ & $\begin{array}{l}\sum \\
\text { 岃 }\end{array}$ & 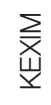 & 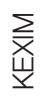 & 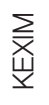 & $\underset{⿱ 亠 凶}{\stackrel{⿱ 亠 乂}{x}}$ & $\begin{array}{l}\text { 离 } \\
\end{array}$ & $\begin{array}{l}\frac{1}{0} \\
\overline{0} \\
\underline{y}\end{array}$ & $\begin{array}{l}\frac{1}{0} \\
\frac{1}{0}\end{array}$ & $\begin{array}{l}\frac{\mathbb{U}}{0} \\
\frac{0}{O}\end{array}$ & $\begin{array}{l}\frac{\pi}{0} \\
\frac{0}{O}\end{array}$ & $\begin{array}{l}\frac{1}{0} \\
\frac{0}{O} \\
\underline{y}\end{array}$ & $\begin{array}{l}\frac{\pi}{0} \\
\frac{0}{O}\end{array}$ & $\begin{array}{l}\frac{\pi}{0} \\
\frac{0}{O}\end{array}$ & $\begin{array}{l}\frac{\pi}{0} \\
\frac{0}{O}\end{array}$ & $\begin{array}{l}\frac{1}{0} \\
\frac{0}{2}\end{array}$ & $\begin{array}{l}\frac{1}{0} \\
\frac{0}{O}\end{array}$ \\
\hline 들 & $\tilde{\bar{\nu}}$ & $\overline{2}$ & ָ̃ & ㅁ & $\overline{\mathcal{D}}$ & ¿ & $\bar{\Sigma}$ & $\stackrel{\sim}{\check{D}}$ & $\bar{\Sigma}$ & ָัָ & $\stackrel{\sim}{2}$ & $\bar{\sim}$ & $\stackrel{m}{\grave{D}}$ & $\stackrel{m}{\grave{D}}$ & D & $\stackrel{m}{\grave{\nu}}$ \\
\hline
\end{tabular}




\begin{tabular}{|c|c|c|c|c|c|c|c|c|c|c|c|c|c|c|c|c|c|c|}
\hline$\frac{\mathcal{N}}{\sum_{S}}$ & 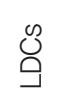 & $\begin{array}{l}\text { y } \\
\text { S }\end{array}$ & 总 & $\stackrel{\mathcal{O}}{\sum}$ & $\stackrel{\mathcal{U}}{\sum}$ & 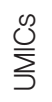 & $\sum_{j}^{\mathcal{O}}$ & O্ & 总 & 岁 & $\stackrel{\infty}{\sum}$ & $\sum_{j}^{\infty}$ & $\stackrel{\mathcal{U}}{\sum}$ & $\stackrel{\mathcal{U}}{\sum}$ & 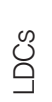 & $\sum_{\Sigma}^{\mathcal{O}}$ & 号 & $\stackrel{\mathcal{U}}{\sum}$ \\
\hline 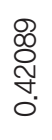 & $\begin{array}{l}\hat{q} \\
\text { 。 } \\
\stackrel{0}{0}\end{array}$ & $\begin{array}{l}\hat{\overline{0}} \\
\stackrel{0}{1} \\
\overline{0} \\
0\end{array}$ & 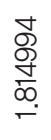 & $\begin{array}{l}\stackrel{0}{8} \\
\stackrel{0}{0} \\
\stackrel{0}{0}\end{array}$ & 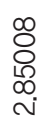 & 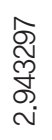 & 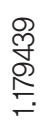 & 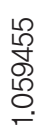 & 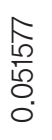 & 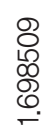 & $\begin{array}{l}\text { 尺 } \\
\stackrel{0}{0} \\
\stackrel{0}{0} \\
\stackrel{0}{\circ}\end{array}$ & 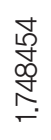 & 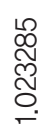 & $\begin{array}{l}\text { 尺్ } \\
\text { م } \\
\text { م. } \\
0\end{array}$ & $\begin{array}{l}\infty \\
\stackrel{\infty}{\infty} \\
\infty \\
\infty \\
0\end{array}$ & 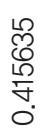 & $\begin{array}{l}\bar{\sigma} \\
\dot{0} \\
0 \\
0 \\
0\end{array}$ & $\begin{array}{l}\widetilde{N} \\
0 \\
0 \\
0 \\
0 \\
0 \\
0\end{array}$ \\
\hline 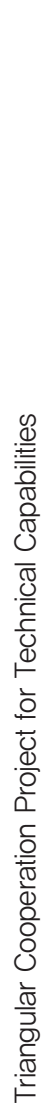 & 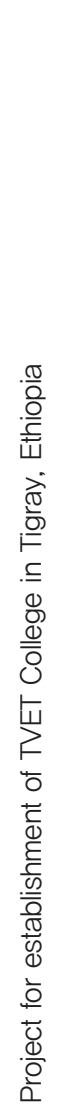 & 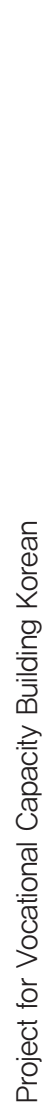 & 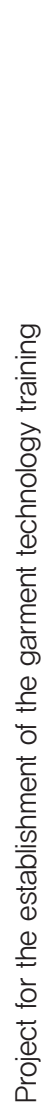 & 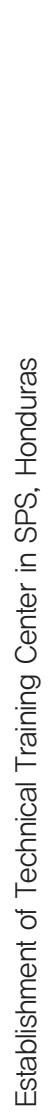 & 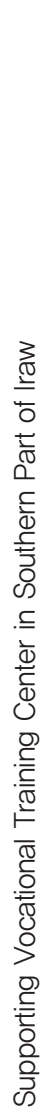 & 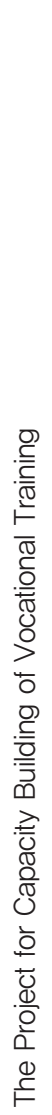 & 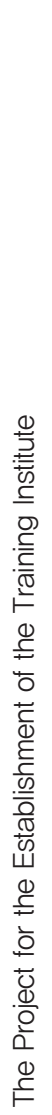 & 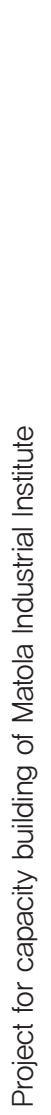 & 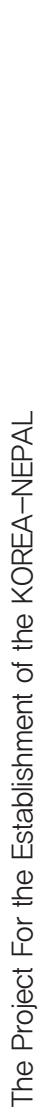 & 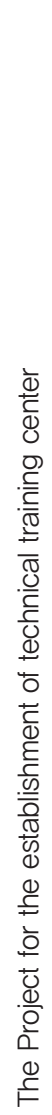 & 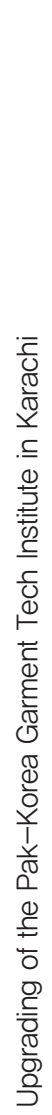 & 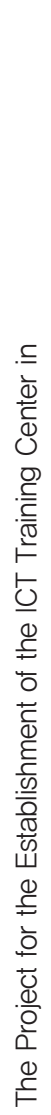 & 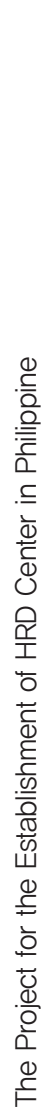 & 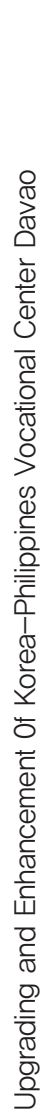 & 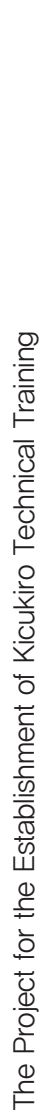 & 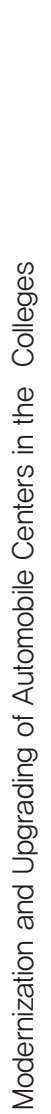 & 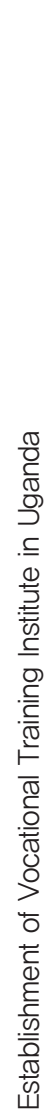 & 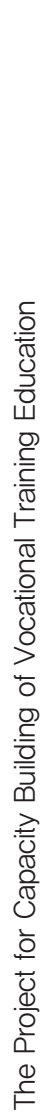 \\
\hline 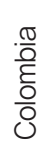 & 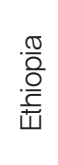 & 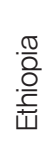 & $\begin{array}{l}\text { : } \frac{\bar{E}}{\bar{T}} \\
\text {. }\end{array}$ & 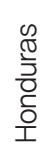 & $\underset{\mathbb{\widetilde { V }}}{\mathbb{\sigma}}$ & $\begin{array}{l}\frac{}{\mathbb{0}} \\
\text { 잉 }\end{array}$ & 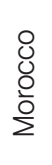 & 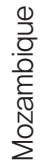 & $\begin{array}{l}\overline{\bar{\Omega}} \\
\frac{\mathrm{d}}{2}\end{array}$ & $\begin{array}{l}\overline{\widetilde{O}} \\
\frac{\mathrm{Q}}{2}\end{array}$ & 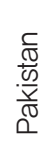 & 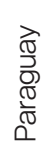 & 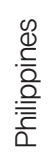 & 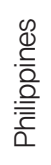 & $\begin{array}{l}\frac{\pi}{0} \\
\frac{\pi}{\mathbb{N}} \\
\frac{\pi}{x} \\
\end{array}$ & 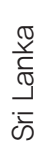 & $\begin{array}{l}\frac{\pi}{0} \\
\mathbb{0} \\
\mathcal{D}\end{array}$ & $\begin{array}{l}\frac{c}{0} \\
\frac{\omega}{0} \\
\frac{D}{D} \\
\frac{N}{N}\end{array}$ \\
\hline $\begin{array}{l}\frac{1}{0} \\
\frac{1}{0} \\
\text { L }\end{array}$ & $\begin{array}{l}\mathbb{J} \\
\bar{O} \\
\underline{O}\end{array}$ & $\begin{array}{l}\frac{1}{0} \\
\overline{0} \\
\underline{y}\end{array}$ & $\begin{array}{l}\frac{1}{0} \\
\overline{0} \\
\underline{y}\end{array}$ & $\begin{array}{l}\frac{1}{0} \\
\text { Oे }\end{array}$ & $\begin{array}{l}\frac{1}{0} \\
\stackrel{0}{0}\end{array}$ & $\begin{array}{l}\frac{1}{0} \\
\frac{0}{0}\end{array}$ & $\begin{array}{l}\frac{1}{0} \\
\frac{1}{0} \\
\text { Q }\end{array}$ & $\begin{array}{l}\frac{1}{0} \\
\stackrel{0}{0} \\
\underline{x}\end{array}$ & $\begin{array}{l}\frac{1}{0} \\
\frac{0}{0} \\
\underline{x}\end{array}$ & $\begin{array}{l}\frac{1}{0} \\
\overline{0} \\
\end{array}$ & $\begin{array}{l}\frac{1}{0} \\
\overline{0} \\
\underline{y}\end{array}$ & $\begin{array}{l}\frac{1}{0} \\
\overline{0} \\
\underline{y}\end{array}$ & $\begin{array}{l}\frac{1}{0} \\
\frac{1}{0}\end{array}$ & $\begin{array}{l}\frac{1}{0} \\
\text { Oे }\end{array}$ & $\begin{array}{l}\frac{1}{0} \\
\frac{0}{2}\end{array}$ & $\begin{array}{l}\frac{1}{0} \\
\stackrel{0}{0}\end{array}$ & $\begin{array}{l}\frac{\mathbb{U}}{0} \\
\bar{O}\end{array}$ & $\begin{array}{l}\frac{1}{0} \\
\frac{0}{0}\end{array}$ \\
\hline$\stackrel{m}{\circ}$ & $\stackrel{m}{\sigma}$ & $\stackrel{m}{\grave{N}}$ & $\stackrel{m}{i}$ & $\stackrel{m}{i}$ & $\stackrel{m}{\circ}$ & $\stackrel{m}{\sim}$ & $\stackrel{m}{\grave{N}}$ & $\stackrel{m}{\grave{N}}$ & $\stackrel{m}{i}$ & $\stackrel{m}{\bar{\sigma}}$ & $\stackrel{m}{\grave{N}}$ & $\stackrel{m}{\grave{N}}$ & $\stackrel{m}{\grave{N}}$ & $\stackrel{m}{\check{N}}$ & $\stackrel{m}{\check{D}}$ & $\stackrel{m}{\check{N}}$ & $\stackrel{m}{i}$ & \\
\hline
\end{tabular}




\begin{tabular}{|c|c|c|c|c|c|c|c|c|c|}
\hline$\stackrel{\mathcal{O}}{\sum}$ & $\sum_{j}^{\mathcal{O}}$ & $\sum_{\Sigma}^{\mathcal{O}}$ & $\sum_{\perp}^{\mathcal{O}}$ & $\sum_{\Sigma}^{\mathcal{N}}$ & $\begin{array}{l}\frac{0}{\mathcal{O}} \\
\overline{\bar{d}} \\
\bar{\Phi} \\
\overline{0}\end{array}$ & $\stackrel{\mathcal{U}}{\sum}$ & $\stackrel{\mathcal{O}}{\sum}$ & $\stackrel{\mathcal{U}}{\sum}$ & $\sum_{\perp}^{\mathcal{O}}$ \\
\hline $\begin{array}{l}\frac{1}{4} \\
\frac{10}{0} \\
0 \\
0 \\
0\end{array}$ & $\begin{array}{l}\widetilde{N} \\
\stackrel{\sim}{N} \\
\stackrel{\sim}{N}\end{array}$ & 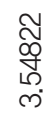 & $\begin{array}{l}\infty \\
0 \\
0 \\
0 \\
0 \\
0\end{array}$ & $\begin{array}{l}\infty \\
\stackrel{\infty}{亡} \\
\stackrel{\sim}{\widetilde{J}} \\
\stackrel{0}{0}\end{array}$ & 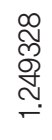 & 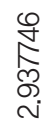 & $\begin{array}{l}\infty \\
\widetilde{N} \\
\stackrel{\leftrightarrow}{\sim} \\
\stackrel{0}{\sigma}\end{array}$ & 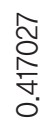 & $\begin{array}{l}\text { o } \\
\text { ô } \\
\text { o } \\
\text { లి. } \\
\text { o. }\end{array}$ \\
\hline 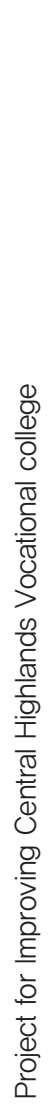 & 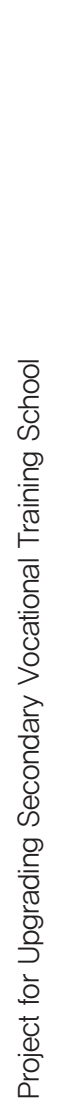 & 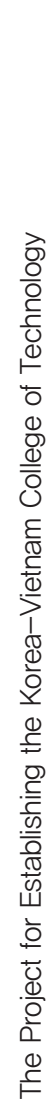 & 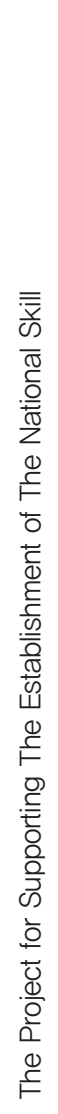 & 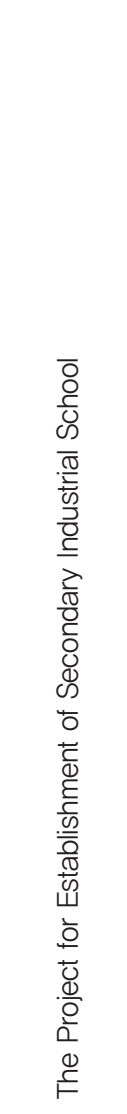 & 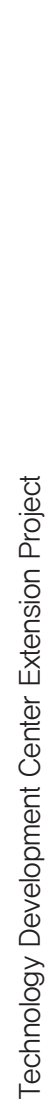 & 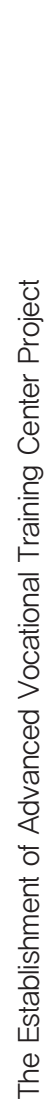 & 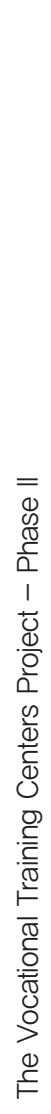 & 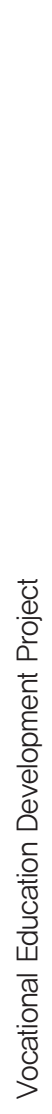 & 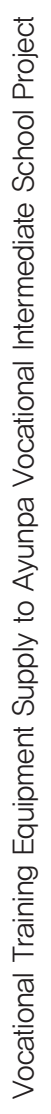 \\
\hline $\begin{array}{l}\frac{E}{N} \\
\sum \\
\frac{\mathbb{N}}{J}\end{array}$ & 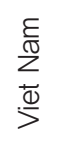 & $\begin{array}{l}\frac{\varepsilon}{\pi} \\
\frac{\pi}{d} \\
j\end{array}$ & $\begin{array}{l}\frac{E}{\pi} \\
\frac{\pi}{0} \\
j\end{array}$ & 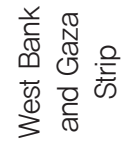 & $\begin{array}{l}\stackrel{\mathbb{a}}{c} \\
\stackrel{\mathbb{Q}}{2}\end{array}$ & 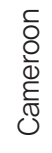 & $\begin{array}{l}\frac{\pi}{3} \\
\frac{\pi}{\pi} \\
\frac{\pi}{\pi} \\
\frac{0}{2}\end{array}$ & $\begin{array}{l}\frac{c}{0} \\
\frac{N}{D N} \\
\frac{Y}{D} \\
\frac{O}{N} \\
D\end{array}$ & 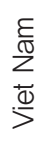 \\
\hline $\begin{array}{l}\frac{\pi}{0} \\
\frac{0}{0} \\
\text { Q }\end{array}$ & $\begin{array}{l}\text { J } \\
\overline{0} \\
\underline{y}\end{array}$ & 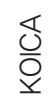 & $\begin{array}{l}\frac{\mathbb{J}}{2} \\
\bar{O}\end{array}$ & $\begin{array}{l}\frac{1}{0} \\
\frac{0}{0}\end{array}$ & 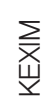 & 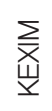 & 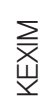 & 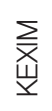 & 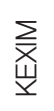 \\
\hline$\stackrel{m}{i}$ & $\stackrel{m}{\sim}$ & m. & $\stackrel{m}{\circ}$ & $\stackrel{m}{i}$ & $\bar{\sim}$ & $\stackrel{m}{\grave{N}}$ & $\stackrel{m}{\bar{\delta}}$ & ֻั & $\stackrel{m}{i}$ \\
\hline
\end{tabular}

제I장

제II장

섹

터

제III장 